
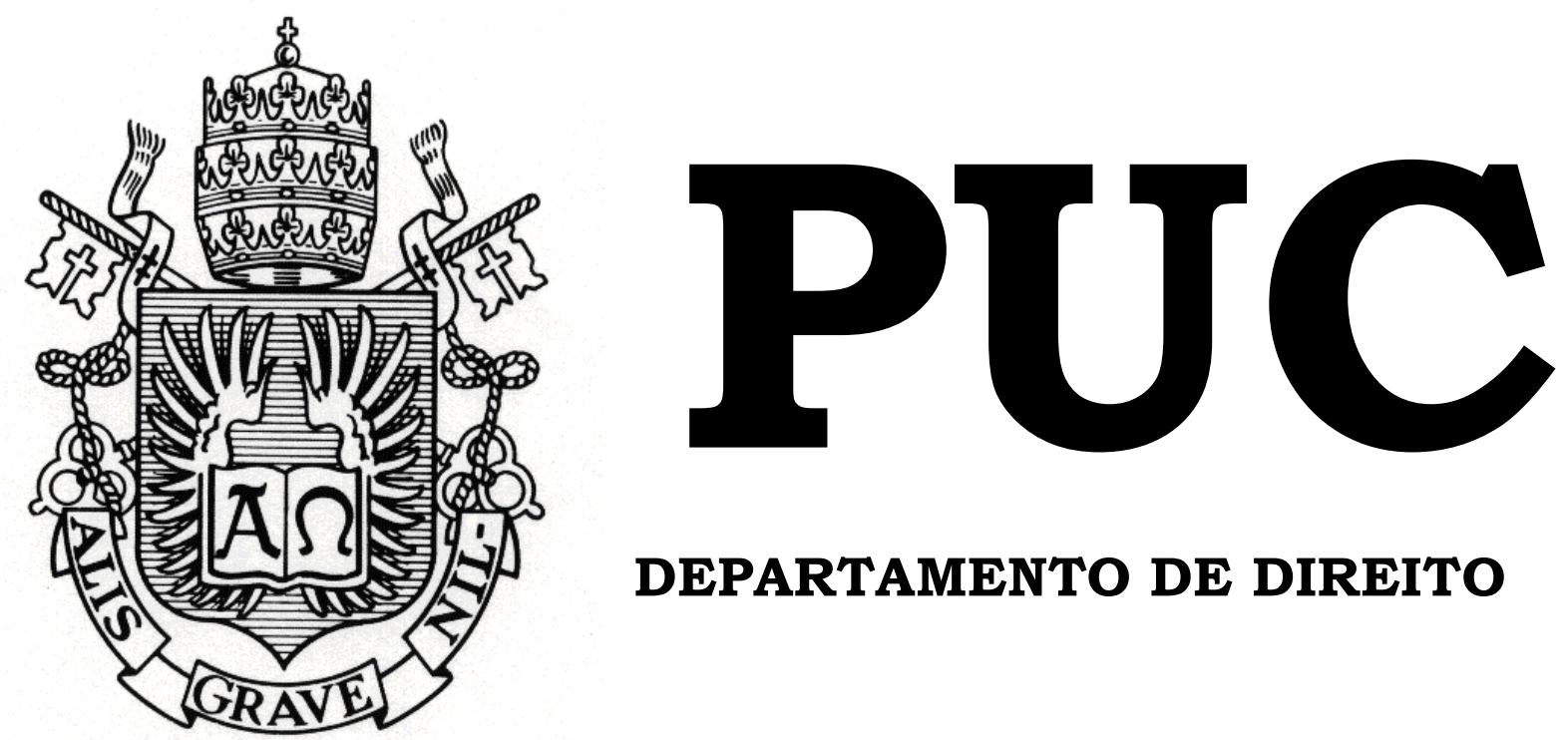

DEPARTAMENTO DE DIREITO

\title{
MITIGAÇÃO DOS DANOS PELO CREDOR: \\ APLICAÇÃO COM BASE \\ NO DIREITO BRASILEIRO \\ E NA CONVENÇÃO DE VIENA \\ DE COMPRA E VENDA INTERNACIONAL \\ DE MERCADORIAS - CISG
}

por

LUCAS MAYALL M. DE ARAUJO

ORIENTADOR: GUILHERME VALDETARO

2013.2

PONTIFÍCIA UNIVERSIDADE CATÓLICA DO RIO DE JANEIRO

RUA MARQUÊS DE SÃO VICENTE, 225 - CEP 22453-900

RIO DE JANEIRO - BRASIL 


\section{MITIGAÇÃO DOS DANOS PELO CREDOR: \\ APLICAÇÃO COM BASE \\ NO DIREITO BRASILEIRO \\ E NA CONVENÇÃO DE VIENA \\ DE COMPRA E VENDA INTERNACIONAL \\ DE MERCADORIAS - CISG}

por

LUCAS MAYALL M. DE ARAUJO

Monografia apresentada ao

Departamento de Direito da

Pontificia Universidade Católica do

Rio de Janeiro (PUC-Rio) como

requisito parcial para obtenção do

título de Bacharel em Direito

Orientador: Guilherme Valdetaro 
Dedico este trabalho aos meus queridos amigos do Grupo de Estudos em Arbitragem e Direito do Comércio Internacional (GEADICI) da PUC-RIO, companheiros de tantas jornadas e lições. Agradeço pelo imenso prazer que foi conviver com vocês ao longo dos últimos anos. 


\section{RESUMO}

ARAUJO, Lucas Mayall M. de. Mitigação dos danos pelo credor: aplicação com base no Direito Brasileiro e na Convenção de Viena de Compra e Venda Internacional de Mercadorias - CISG. Rio de Janeiro, 2013. 87 p. Monografia de final de curso Departamento de Direito, Pontifícia Universidade Católica do Rio de Janeiro.

A presente monografia trata do dever de mitigação de danos imposto à parte credora de indenização por responsabilidade civil. Após um breve histórico, serão abordadas suas características gerais, o papel que o instituto tem a desempenhar no direito brasileiro e a sua aplicação com base na CISG.

Na última década, o tema ganhou relevância no Brasil, mesmo inexistindo norma expressa em nosso ordenamento jurídico a respeito. $\mathrm{O}$ fundamento de sua incorporação, à luz do entendimento doutrinário e jurisprudencial a respeito, é a boa-fé objetiva, da qual o dever de mitigar seria um dever anexo.

A recente adesão do Brasil à CISG amplia a importância do debate, pois a referida convenção tem por uma de suas características marcantes impor ao credor o dever de mitigar os próprios danos, inclusive de forma muito mais severa do que vem sendo aplicado no nosso país.

Assim, revela-se pertinente, neste momento, renovar a discussão a respeito do instituto da mitigação dos danos pelo credor, tanto pela aplicabilidade imediata que a convenção terá sobre os negócios internacionais de que forem partes empresários brasileiros quanto por sua crescente aplicação como dever anexo da boa fé.

Palavras-chave: Direito Civil. Responsabilidade Civil. Mitigação de danos pelo credor. Código Civil. Convenção de Viena de Compra e Venda Internacional de Mercadorias. 


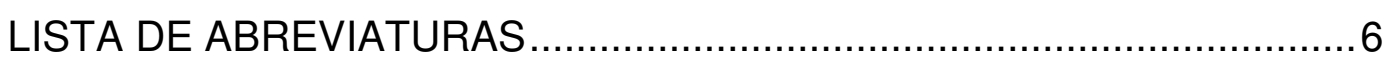

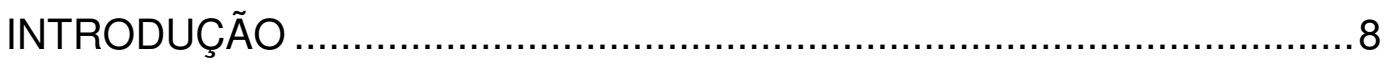

CAPÍTULO I - O CONCEITO DE MITIGAÇÃO DE DANOS PELO

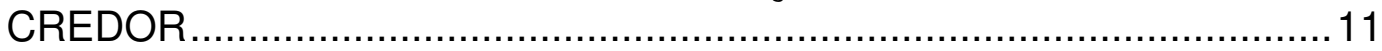

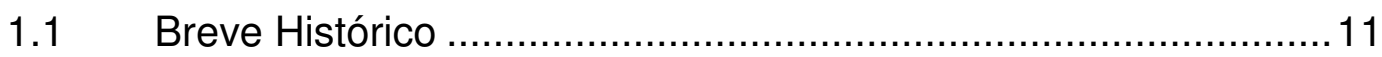

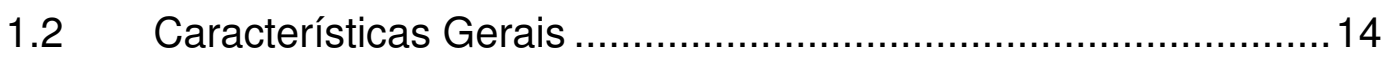

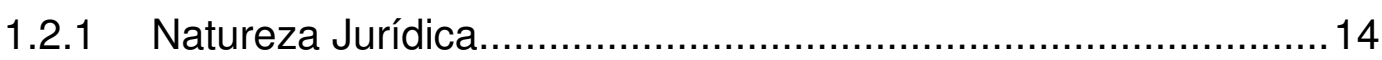

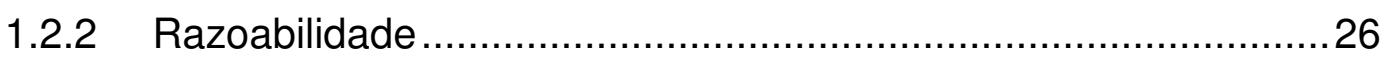

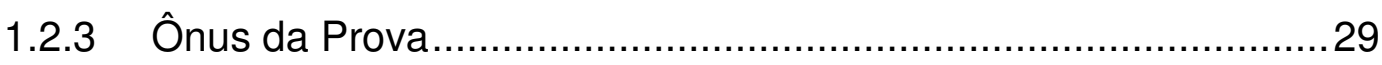

CAPÍTULO II - A APLICAÇÃO DO INSTITUTO NO BRASIL ....................32

2.1 Os Fundamentos da Aplicação do Dever de Mitigar no Brasil ....32

2.2 Análise de Disposições Relacionadas do Código Civil................. 36

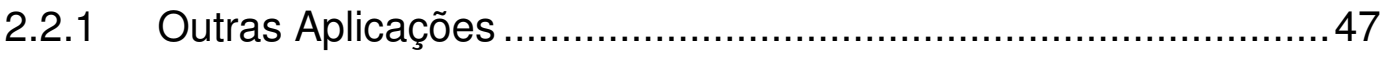

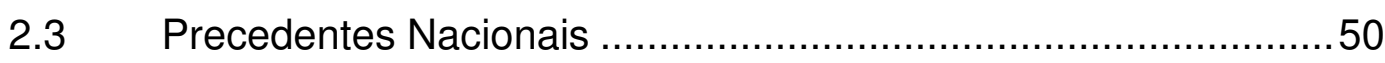

CAPÍTULO III - O DEVER DE MITIGAÇÃO DE DANOS NA CISG ..........67

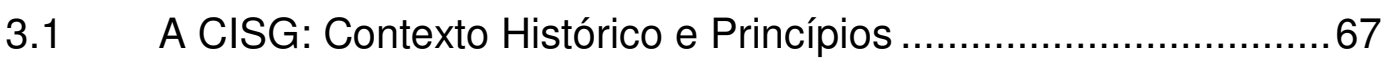

3.2 Os Esforços Conciliatórios na Convenção ..................................... 69

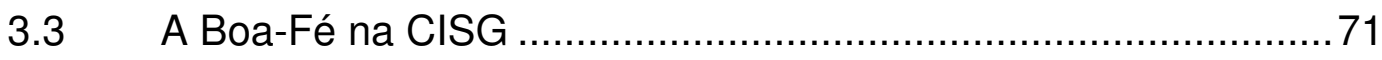

3.4 O dever da parte lesada de mitigar seus danos na CISG ...........73

CONCLUSÃO

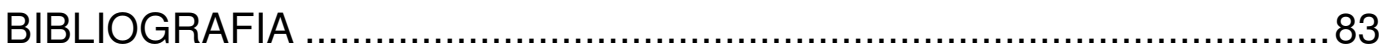


CC - Código Civil

CIETAC - China International Economic and Trade Arbitration Commission

CISG - Convention on Contracts for the International Sale of Goods

CJF - Conselho da Justiça Federal

CPC - Código de Processo Civil

HC - $\quad$ Habeas Corpus

ICC - International Chamber of Commerce

IUSCT - $\quad$ Iran-United States Claims Tribunal

REsp - $\quad$ Recurso Especial

STJ - $\quad$ Superior Tribunal de Justiça

TJRS - $\quad$ Tribunal de Justiça do Rio Grande do Sul

ULIS - Uniform Law on the International Sale of Goods

UNCITRAL - United Nations Commission on International Trade Law

UNIDROIT - International Institute for the Unification of Private Law 
Não há como se negar que o direito civil brasileiro está passando por uma profunda transformação. Cada vez mais, exige-se das partes uma rígida observância de um padrão ético de conduta, conhecido como boa-fé objetiva. Dentre os principais avanços empreendidos nessa área estão as exigências de lealdade e cooperação entre as partes.

Além das óbvias mutações pelas quais o direito civil herdado dos tempos do voluntarismo puro foi submetido, das quais é exemplo a flexibilização de antigos dogmas como a relatividade dos contratos e a intangibilidade do conteúdo obrigacional, vê-se uma série de novos deveres sendo impostos à parte credora da obrigação. Ao contrário de outros tempos, em que só lhe bastava pagar o preço combinado e esperar que a parte devedora tomasse todas as providências necessárias ao cumprimento do que fora pactuado, hoje o credor possui um dever de contribuir, na medida do que for possível e razoável, para o adimplemento das obrigações e de não agravar a posição da outra parte por sua conduta.

No entanto, apenas recentemente iniciou-se, no Brasil, um debate a respeito do dever do credor de mitigar seus danos, sob pena de não poder cobra-los, ao menos em sua integralidade, da parte inadimplente. Este instituto existe nos países europeus há pelo menos um século, ou seja, antes mesmo do surgimento da noção de boa-fé objetiva como a conhecemos. Ainda assim, tem sido largamente aceito como uma clara manifestação da boa-fé objetiva. Não pode o credor, após ver o contrato ser inadimplido pela outra parte, agir como se uma guerra houvesse eclodido entre ele e o devedor, permitindo, quase por vingança, que seus danos se alastrem indefinidamente apenas para submeter a parte contrária ao pagamento de uma indenização maior. Pelo contrário, o que se espera de uma parte séria e pautada pela boa fé, é que busque sempre minorar seus danos. Sem que seja compelido para tanto, nem sempre o credor observará tal postura. 
Comumente, esta mitigação é realizada por meio de transações substitutas. No entanto, somente a criatividade, de um lado, e a razoabilidade, de outro, é que vão determinar, à luz do caso concreto, o que, de fato, poderá o credor fazer para mitigar seus danos. Em muitos casos, não será possível ao credor tomar qualquer providência para mitigar o seu dano e nem por isso deverá ele sofrer qualquer limitação em seu direito. $\mathrm{O}$ objetivo deste dever é sempre o de impedir a produção de danos evitáveis e não subverter a lógica da responsabilidade civil.

A Convenção de Viena é um importante marco do direito civil e do comércio mundial. Formada a partir de um esforço sem precedentes - e, como se verá, bem sucedido - para reunir nações dos mais diversos ordenamentos jurídicos, a CISG representa um denominador comum de todas as diferentes experiências legais. Como foi formulada para um ambiente naturalmente marcado pela incerteza, o comércio internacional, a CISG prevê normas simples e passa uma mensagem clara às partes de que elas devem sempre tomar todas as providências possíveis para cumprir os contratos e impedir sua resolução sem que todas as medidas possíveis para conserva-lo sejam tomadas.

Uma de suas disposições mais comentadas é o art. 77, no qual está previsto o dever do credor de mitigar seu próprio dano. A primeira vista, a aludida norma pode parecer contra intuitiva e mesmo injusta. Afinal, por que uma parte que já foi prejudicada pelo inadimplemento da outra deveria se preocupar com diminuir seus próprios danos se seu parceiro não foi capaz de demonstrar o mesmo cuidado ao inadimplir o contrato? Nesta monografia serão analisadas as situações em que se pode aplicar o referido instituto, demonstrando-se que não há qualquer injustiça cometida quando se aplica corretamente o dever de mitigar o próprio dano.

O estudo é relevante não apenas pela incorporação da CISG ao direito nacional, como, também, para que se veja a forma açodada e atécnica que o princípio for incorporado, do que são exemplos as decisões do STJ tratando do tema. Analisados os julgados, é questionável se houve, 
de fato, uma aplicação efetiva do instituto. Como se verá, o dever de mitigação vem sendo aplicado muito mais como uma ideia geral do que como uma regra específica e isso vem sendo feito em detrimento de outras normas aplicáveis aos casos concretos.

A análise da aplicação do dever de mitigar com base na CISG, feita por tribunais muito mais acostumados a aplica-lo respeitando outros institutos, pode servir de base de comparação para que se percebam eventuais equívocos que vem sendo praticados no Brasil. Ademais, tendo em vista o caráter internacional da CISG e a necessidade de preservação da uniformidade em sua interpretação (CISG, art. 7, I), é importante que os operadores do direito no Brasil se familiarizem com o art. 77 e seu conteúdo, pois em breve este será diretamente aplicável à maioria dos contratos internacionais de que forem parte empresas brasileiras. 


\section{CAPÍTULO I - O CONCEITO DE MITIGAÇÃO DE DANOS PELO CREDOR}

1.1 Breve Histórico 1.2 Características Gerais 1.2.1 Natureza Jurídica 1.2.2 Razoabilidade 1.2.3 Ônus da Prova

\section{$1.1 \quad$ Breve Histórico}

A imposição do dever de mitigar o próprio dano à parte prejudicada (aggrieved party) ou credora de indenização por responsabilidade civil é frequentemente associada ao direito inglês, no qual há muito se encontra presente. Historicamente, considera-se um caso julgado pela Câmara dos Lordes em 1912 como o principal marco do reconhecimento de tal obrigação ${ }^{1}$.

A disputa envolveu a Metropolitan District Electric Traction Company e a British Westinghouse, tendo a primeira adquirido da última oito turbinas e igual número de alternadores para a construção de uma estação na região de Chelsea, no centro de Londres, ao preço de $£ 250,000^{2}$. Os bens entregues pela vendedora, no entanto, não tiveram a performance desejada, consumindo mais vapor do que fora pactuado. Assim, a compradora contratou turbinas substitutas, produzidas pela C. A. Parsons \& Co., do inventor da turbina a vapor, Charles Parsons. Estas turbinas substitutas tiveram rendimento até mesmo superior ao acordado inicialmente pela Metropolitan Disctrict Electric Traction Company com a British Westinghouse.

A demanda começou por iniciativa da parte vendedora, que pleiteava uma parcela não paga do contrato, no valor de £85,398. A London Underground, que, por meio de fusão, sucedia em seus direitos e obrigações

\footnotetext{
${ }^{1}$ DIAS, Daniel Pires de Novais. O Duty to Mitigate the Loss no Direito Civil Brasileiro e o Encargo de Mitigar o Próprio Dano. In: TEPEDINO, Gustavo; FACHIN, Edson. Revista dos Tribunais. Doutrinas Essenciais: Obrigações e Contratos, vol. III. São Paulo: Editora Revista dos Tribunais, p. 692.

2 DYSON, Andrew. British Westinghouse Revisited. Disponível em $<$ http://www.academia.edu/1987110/British_Westinghouse_Revisited $>$. Data de Acesso 5/10/13.
} 
à Metropolitan District Electric Traction Company, apresentou reconvenção com base nos defeitos dos bens entregues. O pedido formulado incluía (i) o valor do custo extra de carvão que teve de ser utilizado na máquina devido ao consumo excessivo de vapor até o dia em que as turbinas contratadas junto à Parsons \& Co. entraram em funcionamento, além de custos de reposição e (ii) o valor de $£ 237,728$ correspondentes ao custo extra de carvão por toda a vida útil dos bens entregues pela vendedora, ainda que estes não fossem utilizados, ou, alternativamente, o valor de $£ 78,226$, custo da contratação e instalação das peças da Parsons \& Co.

Por meio de sucessivos recursos a causa foi julgada pela Câmara dos Lordes, que afirmou que a indenização deveria corresponder ao valor da compra das novas máquinas, incluindo-se o gasto extra com carvão apenas até o momento da transação substituta. Embora muitos aspectos possam ser destacados desse julgado, como a discussão do dano efetivo e as consequências jurídicas do avanço tecnológico pelo qual passava o mercado de turbinas a vapor - comparável ao mercado de processadores para computador hoje em dia - e a real existência de nexo entre o inadimplemento e a transação, deve ser registrado o trecho no qual se estabelece a regra de que a parte deve tomar medidas razoáveis para mitigar seus danos:

The fundamental basis is thus compensation for pecuniary loss naturally flowing from the breach; but this first principle is qualified by a second, which imposes on a plaintiff the duty of taking all reasonable steps to mitigate the loss consequent on the breach, and debars him from claiming in respect of any part of the damage which is due to his neglect to take such steps. ${ }^{3}$

Outros autores, no entanto, apontam o Código Civil Alemão elaborado em 1896 e que entrou em vigor em 1900 (Bürgerliches Gesetzbuch - BGB) como a fonte a partir da qual o instituto se espalhou para os demais ordenamentos jurídicos ${ }^{4}$. O referido Código prevê, em seu $\S$ 254, o conceito de "negligência contributiva", que mais se assemelhe ao

\footnotetext{
${ }^{3}$ Idem.

${ }^{4}$ DIAS, Daniel Pires Novais, op. cit., p. 692.
} 
nosso conceito de concorrência de condutas, no qual a atuação do credor, ativa ou passiva, interfere no próprio evento danoso, e não necessariamente num agravamento do dano causado pela outra parte. No entanto, no final de seu item (2), o aludido artigo prevê sua extensão à mitigação do dano, diversamente do nosso art. 945:

$\S 254$ (Participação na culpa).

(1) Se, na produção do dano, concorrer uma culpa do prejudicado, dependerá a obrigação à indenização, bem como o alcance da indenização a prestar, das circunstâncias, particularmente do fato de que até que ponto o dano foi, preponderantemente, por uma ou outra parte, causado.

(2) Aplica-se isto, mesmo quando a culpa do prejudicado se limita à circunstância de que negligenciou ele de chamar a atenção do devedor sobre o perigo de um dano inteiramente excepcional que o devedor não conhecia nem era obrigado a conhecer, ou de que negligenciou ele de afastar ou de minorar o dano

Independente de sua origem, é inegável a relevância da aplicação do referido princípio. Atualmente, o dever do credor de mitigar seus danos encontra-se previsto em importantes conjuntos de regras internacionais, como os princípios do UNIDTROIT $^{5}$ e da Common European Contract Sales Law ${ }^{6}$. Mais notadamente, como será detidamente abordado neste trabalho, o dever de mitigar o próprio dano está previsto no art. 77 da CISG.

Por fim, embora tais temas fujam ao escopo do presente trabalho devido às diversas particularidades a eles inerentes e por sua distância da realidade brasileira, aplica-se o dever do credor de mitigar seus próprios danos nas arbitragens de investimento (ICSID), envolvendo investidores e os 158 países signatários da convenção de Washington ${ }^{7}$, assim como

\footnotetext{
${ }^{5}$ Princípios do UNIDROIT (2010) - art. 7.4.8: (I) The non-performing. party is not liable for harm suffered by the aggrieved party to the extent that the harm could have been reduced by the latter party' s taking reasonable steps.

(2) The aggrieved party is entitled to recover any expenses reasonably incurred in attempting to reduce the harm.

${ }^{6}$ Art. 163: 1. The debtor is not liable for loss suffered by the creditor to the extent that the creditor could have reduced the loss by taking reasonable steps.

2. The creditor is entitled to recover any expenses reasonably incurred in attempting to reduce the loss.

${ }^{7}$ PRAGER, Dietmar; FRISCHTAK, Ana. Duke Energy International Peru Investments No. 1, Ltd. v. Republic of Peru, Award, ICSID Case No. ARB/03/28, 18 August 2008: a contribution by the ITA Board of Reporters. Disponível em $<$ http://www.kluwerarbitration.com/CommonUI/document.aspx?id=ipn91204\&query=AND(ONE
} 
aplicou-se o referido instituto no Tribunal especificamente constituído para a resolução de controvérsias entre partes americanas e iranianas quando da Revolução Islâmica no Irã (IUSCT) ${ }^{8}$.

\subsection{Características Gerais}

Embora não seja possível afirmar que se trata de uma regra de direito aplicada de forma completamente homogênea ao redor do mundo, é possível traçar algumas das principais características do dever do credor de mitigar seus danos. Assim, este capítulo introdutório cuidará das principais características do dever do credor de mitigar o próprio dano.

\subsubsection{Natureza Jurídica}

Uma das principais discussões a respeito do dever do credor de mitigar seus próprios danos é a sua natureza jurídica. Conquanto a expressão em inglês - duty to mitigate the loss (ou duty to mitigate damages) —, traduzida para dever de mitigar danos (forma pela qual será referido aqui, para evitar o desnecessário anglicismo), pareça sugerir que se trata de uma obrigação, há grande controvérsia sobre tal classificação.

Um dos motivos pelo qual debate-se a natureza jurídica do dever de mitigação dos danos é o fato de receber tratamento diverso nos países que o preveem. Apesar do resultado prático ser essencialmente o mesmo, o dever de mitigação encontrou diferentes formas de ser recepcionado ao redor do mundo. Conforme leciona Vera Maria Fradera, os alemães a classificam como uma obliegenheit, sobre qual a autora assim discorre:

a) A noção de Obliegenheit tem sua fonte no direito alemão de seguros, tendo Reimer Schimdt buscado realizar a sua sistematização, a partir da

AR/0(content $\% 3 \mathrm{~A} \% 22$ mitigation $\% 22$, content $\% 3 \mathrm{~A} \% 22$ of $\% 22$, content $\% 3 \mathrm{~A} \% 22$ damages $\% 22$ ), con tent $\% 3 \mathrm{~A} \% 22$ reasonability\%22)>. Acesso em 26/9/13.

${ }^{8}$ IUSCT. Procedimento no 430 (438-430-1), julgado em 5 set. 1989. Publicado em BERG, Albert Jan van den (ed), Yearbook Commercial Arbitration 1990 - Volume XV, Kluwer Law International: 1990, pp. 239-255. 
construção de um sistema geral de obrigações, onde seriam incluídas todas as obrigações anexas, os ônus ou incumbências e os deveres para consigo mesmo. Segundo afirmou Clóvis do Couto e Silva, esta tentativa não teve maior êxito. Contudo, o mesmo autor esclarece permanecerem atuais os estudos de Reimer Schmidt relativamente a certos deveres anexos, v.g., a descoberta de deveres anexos de menor intensidade de coação ou deveres de grau menor. ${ }^{9}$

Mais adiante, prossegue a autora:

A expressão obliengenheit surgiu no âmbito do direito dos seguros, no direito alemão, tendo o sentido de um dever de menor intensidade, contudo, a sua obediência está no interesse desta pessoa. Segundo adverte Christoph Fabian, o sistema jurídico não prevê um direito à indenização, apenas uma sanção, de natureza mais leve, como por exemplo, a perda de uma posição jurídica favorável. ${ }^{10}$

Segundo a autora, na Suíça, o dever de mitigar teria sido incorporado sob a forma de uma incombance. A autora, contudo, não parece diferenciar o tratamento dado por alemães e suíços, dando a entender que se trata de mera questão de tradução do termo:

Já os autores suíços cunharam a expressão incombance para designar este tipo de dever. O termo provém do verbo latino incumbere, cujo sentido é o de pesar, onerar. Sendo o Código suíço redigido em língua francesa, seu legislador adotou o substantivo incombance. ${ }^{1}$

Interessante é a forma que a questão é tratada na França. Mais uma vez recorrendo à lição de Vera Fradera, vê-se que naquele país, o dever de mitigar os próprios danos é aplicado com base em outras figuras tipicamente ligadas ao princípio da boa-fé objetiva, o venire contra factum proprium e o abuso de direito:

Ainda sendo um país bastante reticente na recepção do conceito de boa fé objetiva, a jurisprudência francesa vem adotando o dever de mitigar o próprio prejuízo, com fulcro no princípio da boa fé.

O mais interessante de tudo isso, é que a jurisprudência francesa utiliza outro conceito, também derivado da boa fé, o da proibição de venire contra factum proprium, como justificativa para sancionar o comportamento do credor faltoso, em relação à l'obligation de mitigation. A título de exemplo, vale referir

\footnotetext{
${ }^{9}$ FRADERA, Vera Maria Jacob de. Pode o credor ser instado a diminuir o próprio prejuízo? Revista Trimestral de Direito Civil no 19, p. 114.

${ }^{10}$ Idem, p. 114.

${ }^{11}$ Ibid, p. 114.
} 
o caso Bailleux c. Jarretty, onde um locador permaneceu durante 11 anos sem cobrar os aluguéis, e, ao invocar a cláusula resolutória, acaba sendo privado de exercer o seu direito, com fundamento na proibição de venire contra factum proprium.

Outra maneira encontrada pelos juízes franceses, para solucionar a problemáticas do descumprimento do dever de mitigar o próprio prejuízo, está na invocação da ocorrência de abuso de direito, conceito tão caro à doutrina daquele país. $^{12}$

Vemos, nos três exemplos, alguns dos principais pontos a serem discutidos em relação ao dever de mitigar os danos. Tanto no caso da Alemanha quanto no da Suíça, fica evidente um dilema em tratar o dever de mitigar os danos como uma obrigação propriamente dita. Isso porque a obrigação é um vínculo que se caracteriza pela possibilidade de que a outra parte exija um determinado comportamento da outra. Na definição de Caio Mário:

“(...) obrigação é o vínculo jurídico em virtude do qual uma pessoa pode exigir de outra prestação economicamente apreciável."13

Veja-se que a definição do autor realça características já apontadas por outros autores que o precederam, os quais cita em sua tradicional obra:

"Regressando ao direito de nosso tempo, e examinando as definições que fizeram carreira, nelas vemos com efeito vibrar a constância de certas tônicas, aliás, não dissonantes dos conceitos clássicos.

Savigny, por exemplo, minucioso e frio, ensina: 'A obrigação consiste na dominação sobre uma pessoa estranha, não sobre toda a pessoa (pois que isto importaria em absorção da personalidade), mas sobre atos isolados, que seriam considerados como restrição à sua personalidade, ou sujeição à nossa vontade.

Mais sucinto é Vittorio Polacco, quando diz da obrigação: 'Relação jurídica patrimonial da qual o devedor é vinculado a uma prestação de índole positiva ou negativa para com o credor.'

Mais analítico é Giorgi: 'Um vínculo jurídico entre duas ou mais pessoas determinadas, em virtude do qual uma ou mais delas (devedor ou devedores) são sujeitas à outra ou às outras (credores ou credores) a fazer ou não fazer qualquer coisa.

Muito extenso, Clóvis Beviláqua define: 'Relação transitória de direito, que nos constrange a dar, fazer ou não fazer alguma coisa, em regra economicamente apreciável, em proveito de alguém que, por ato nosso ou de alguém conosco juridicamente relacionado, ou em virtude da lei, adquiriu o direito de exigir de nós esta ação ou omissão'.

\footnotetext{
${ }^{12}$ Ibid, p. 115.

${ }^{13}$ PEREIRA, Cáio Mário da Silva. Instituiçães de Direito Civil. vol. II. 13a edição, Rio de Janeiro: Editora Forense, 2009, p. 7.
} 
Deste, aproximado o Prof. Washington de Barros Monteiro: 'Obrigação é a relação jurídica, de caráter transitório, estabelecida entre devedor e credor, e cujo objeto consiste numa prestação pessoal econômica, positiva ou negativa, devida pelo primeiro ao segundo, garantindo-lhe o adimplemento através de seu patrimônio.'

Já o nosso Coelho da Rocha definia-a como 'o vínculo jurídico pelo qual alguém está adstrito a dar, fazer ou não fazer alguma coisa', que Lacerda de Almeida observa ser quase ipsis litteris a definição das Institutas."

Conforme enfatizado tanto por Caio Mário quanto pelos ilustres doutrinadores por ele citados, uma obrigação tem por característica primordial a possibilidade de exigência de seu cumprimento pela outra parte. Este, certamente, não é o caso do dever de mitigação de danos.

O uzbeque Djakhongir Saidov, professor de direito comercial internacional na faculdade de Birmingham (Reino Unido), é um dos comentaristas da CISG que apontam para o problema de se tratar o dever de mitigar como uma "obrigação" do credor. O aludido autor critica, ainda, a posição do professor Joseph Lookofsky, segundo o qual o dever de mitigar seria uma obrigação consigo próprio:

"Another issue, which needs to be considered, is that of the 'status' of this provision. It has been formulated as if it imposes an obligation on the party: '[a] party... must take such measures'. But does it really represent an obligation as such?

Some sources state that the provision in Article 77 is one of several provisions of the Convention (together with Articles 85-88), which provide for a 'duty owed by the injured party to the party in breach'. On the other hand, it has been stated that under this provision the injured party 'is under an 'obligation to herself' to mitigate her loss.' It seems that both of these opinions cannot be fully accepted as correct.

First, an obligation can be defined as a legal relationship, by virtue of which one party is entitled to demand from the other party the performance of certain actions. On the basis of Article 77, the breaching party cannot demand from the injured party the performance of this 'duty'. Therefore, the injured party does not, in fact, owe such a 'duty' to the party in breach.

Secondly, we cannot, properly speaking, refer to mitigation as to 'an obligation to [him] herself.' It would contradict the essence of an obligation as a legal concept and, consequently, the party 'cannot owe a duty to him[her]self.'

Thus, we can see that even if it is possible to refer to mitigation using such terms as a 'duty' or an 'obligation,' the nature of this 'duty' is substantially different from other obligations under the CISG. In fact, it does not represent a contractual obligation. There are two principal reasons for such a conclusion.

The first reason has already been touched upon, but will be reiterated again: the 'duty' under Article 77 does not represent a legal relationship between

\footnotetext{
${ }^{14}$ Idem, p. 6.
} 
the parties which gives one party the right to demand a certain action from the other.

Secondly, the breach of an obligation is the basis for liability under the Convention. However, the breach of the 'duty' to mitigate will not give rise to any form of liability under the CISG. Non-compliance with Article 77 will entail the loss by the injured party of the right to claim those damages which could have been avoided. Therefore, the view that this provision can conduce to development of a general principle which would establish a duty of 'loyalty to the other party to the contract', the breach of which results in damages, is not supported in this work.

In one respect, however, it seems that the 'duty' to mitigate may represent the basis for refusal to enforce the party's right to specific performance. Nevertheless, even in that context, this provision should not be construed as an obligation in a legal sense. Its function will be the prevention of the party's exercising his right to the remedy of specific performance.

The opinion, expressed in this work, with respect to the status of the 'duty' to mitigate is in line with the approach taken in English law. The relevant position has been formulated as follows: "A plaintiff is under no duty to mitigate his loss, despite the habitual use by the lawyers of the phrase "duty to mitigate". He is completely free to act as he judges to be in his best interests".,"15

No trecho acima reproduzido, o autor enfrenta a impossibilidade de qualificação do dever de mitigação como uma obrigação. Veja-se que ele afirma categoricamente que “o 'dever' previsto no art. 77 não representa uma relação jurídica entre as partes que dê a uma o direito de demandar da outra uma ação".

No mesmo sentido, veja-se, ainda, a lição de Alexander Komarov:

"In the context of the notion of mitigating damages, reference is often made to a 'duty' to mitigate damages, but at the same time this mode of expression is often and justly criticized. The main reason, of course, is that this 'duty' is not matched by any corresponding right of the defendant ensuring that mitigation takes place. As a consequence, there is no sanction for 'breach' of this 'duty'; the only possible result of the plaintiff's failure to mitigate is to reduce the amount of his recovery. Strictly speaking, he does not incur any legal liability in consequence of the breach of "duty'."16

Como se vê, também o autor russo enfatiza o ponto de que o devedor não adquire qualquer direito com seu inadimplemento. Este é um ponto crucial: sob nenhuma hipótese, pode ser considerado que o devedor, após

\footnotetext{
15 SAIDOV, Djakhongir. Methods of Limiting Damages under the Vienna Convention on Contracts for the International Sale of Goods. Disponível em http://cisgw3.law.pace.edu/cisg/biblio/saidov.html\#iv. Acesso em 10/10/13.

${ }_{16}$ KOMAROV, Alexander. Mitigation of Damages. In DERRAINS, Yves e KREINDLER, Richard (coord.), Evaluation of Damages in International Arbitration. Paris: International Chamber of Commerce. 2006, p. 37.
} 
inadimplir o contrato teria um direito subjetivo de exigir do credor que este mitigue os danos. Não é isso o que significa o dever de mitigação, até mesmo porque seria absolutamente contraditório que seu próprio inadimplemento fosse uma fonte de direitos para o devedor. Para que a questão fique ainda mais clara, jamais poderia, por exemplo, o devedor ajuizar uma demanda exigindo do credor a mitigação de seus próprios danos.

Como bem salientado pelo Prof. Saidov, trata-se de uma decisão que compete exclusivamente ao credor, muito por óbvio, sob o risco de ver reduzido o valor que poderá cobrar a título de indenização.

Essa parece ser a posição mais correta. $\mathrm{O}$ traço definidor da natureza jurídica do dever de mitigar os danos é que ele não pode ser exigido pelo devedor. Trata-se, pura e simplesmente, da perda parcial de uma posição jurídica - a de poder cobrar a totalidade dos danos sofridos em virtude do inadimplemento do devedor - , em virtude do não cumprimento de tal dever.

A discussão, principalmente no Brasil, gira em torno da qualificação do dever de mitigar danos como um dever instrumental da boa-fé ou, como querem alguns ${ }^{17}$, um encargo. Para que se possa compreender a discussão, é necessário, mais uma vez, recorrer às lições de Caio Mário da Silva Pereira, agora no que toca à definição de encargo:

\section{"100. Encargo}

Entre as limitações da vontade, na categoria de elemento acessório, está o encargo, também chamado modo ou modus, que se apresenta como restrição à vantagem criada para o beneficiário de um negócio jurídico, quer estabelecendo o fim a que se destina a coisa adquirida, quer impondo uma obrigação ao

\footnotetext{
17 “2. O encargo de evitar o próprio dano deve ser reconhecido no direito civil brasileiro porque ele é a figura dogmática mais adequada para suprir a lacuna apontada acima acerca da ausência de prescrição jurídica titularizada pela vítima em evitar a produção ou agravamento de danosa si. Como visto, essa lacuna prejudica os elementos do nexo de causalidade e da culpa (da vítima) em relação ao próprio dano, necessários para que este possa ser-lhe imputado em alguma medida. Nas situações em que a vítima de dano permanecer inerte diante da produção ou o agravamento do próprio prejuízo o nexo de causalidade entre a sua conduta e o dano estará estabelecido e decorrerá da inobservância do encargo de evitar o próprio dano. E a culpa, por sua vez, corresponde à falta de diligência que o direito exige no não acatar do encargo de não concorrer para o próprio dano ou o seu agravamento, para a atuação das sanções respectivas.” DIAS, Daniel Pires Novais. op. cit., p. 718.
} 
favorecido em benefício do próprio instituidor, ou de terceiro, ou da coletividade anônima. Mas não constitui, nem pode constituir uma contrapartida da prestação recebida, e, quando se institui em um contrato bilateral, e a obrigação se configura como correlata da prestação devida pela outra, não está caracterizado o modus. Menos, portanto, do que um correspectivo do recebido, é mais do que uma recomendação ou um conselho ao beneficiado, porque feito com caráter impositivo, e sancionado pela exigibilidade a que o obrigado se sujeito. Ninguém pode ser compelido a aceitar uma liberalidade (doação ou legado), mas indo esta acompanhada de um encargo, a sua aceitação implica subordinação do benefício recebido ao dever imposto sob a forma do modus."18

De fato, a definição do dever de mitigação como um encargo é apropriada em relação aos efeitos produzidos. À semelhança do encargo, o dever de mitigar os danos, uma vez descumprido, acarretará na perda de uma posição jurídica favorável a que tinha direito o credor (o direito à indenização). De igual modo, tanto no encargo quanto no dever de mitigar os danos, não há qualquer direito correspondente conferido a outra parte.

Pela definição de Caio Mário, no entanto, o encargo é um elemento acessório a um negócio jurídico, como uma limitação no exercício do direito adquirido a título gratuito por uma pessoa decorrente vontade do donatário. Nasce ele, portanto, no momento em que aperfeiçoado um negócio jurídico.

O dever de mitigar danos, por sua vez, além de poder ocorrer em relação à responsabilidade civil aquiliana — o que será abordado nesta monografia - , só nasce para a parte quando da verificação de um fato, qual seja, o inadimplemento contratual pela outra parte. Não custa lembrar, quando se refere ao dever do credor de mitigar seus danos, a pessoa a quem se está referindo não é o credor da obrigação principal, mas sim o credor da indenização. Afinal, nada impede que seja o devedor da obrigação principal o credor da indenização decorrente da responsabilidade civil de sua contraparte. Nem por isso existirá qualquer distinção quanto ao seu dever de mitigar danos.

No entanto, recorrendo-se a outras fontes doutrinárias, observa-se que o conceito de ônus é mais amplo do que a definição de encargo

\footnotetext{
${ }^{18}$ PEREIRA, Cáio Mário da Silva. Instituições de Direito Civil. vol. I. $22^{\mathrm{a}}$ edição, Rio de Janeiro: Editora Forense, 2008, p. 580.
} 
utilizada por Caio Mario. Enquanto o encargo é associado a um negócio jurídico gratuito, as definições de Perlingieri e de Trabucchi quanto ao ônus parecem abarcar toda e qualquer hipótese em que se está diante de um conduta que, caso não seja tomada, levará ao enfraquecimento de uma posição jurídica favorável:

"Del tutto diversa è la subordinazione in cui viene a trovarsi il sogetto sottoposto a un onere. Nell'onere, il sacrificio dell'interesse proprio è imposto con riguardo a un altro interesse proprio, e pertanto la relativa imposizione corrisponde a un comando finale stabilito in vista del raggiungimento di in determinato fine, quasi per una norma tecnica. Esempio di obbligo: il debitore deve pagare (norma etica); esempio di onere: l'acquirente, se vuole assicurarsi assicurarsi contro altre alienazioni del bene immobile acquistato, deve sottoporsi alle formalità della transcriozione (imperativo ipotetico)."19

"Ônus: dito obrigação potestativa. - O ônus pode ser definido - com expressão de conveniência - como uma obrigação potestativa, no sentido de que o seu titular pode realiza-lo ou não. Poder-se-ia, justamente, objetar que não é possível falar de obrigação ou de dever deixado à discricionariedade do sujeito obrigado, de maneira que falte a um outro sujeito o direito de exigir o adimplemento. A configuração utilizada ajuda a evidenciar que existem situações passivas que não vinculam o sujeito titular o qual, com base numa própria avaliação discricional, poderá exercê-las, ou não. O ônus não é somente uma 'obrigação potestativa', deixada ao arbítrio do obrigado, antes, representa uma situação instrumental para alcançar um resultado útil (interesse) do titular."

Tratando dos contratos de seguros, os quais, como visto acima, foram a fonte inspiradora da criação dos obliegenheit no direito alemão, Pontes de Miranda apresenta uma definição dos ônus do segurado que muito parecem com o dever de mitigação:

"O segurado tem o ônus de gestão de seu próprio negócio, dito ônus de cuidar do risco ou onnus de salvamento, por analogia com o segurado em outros seguros. Tem de tomar todas as medidas que sejam indispensáveis à existência, à eficácia e à integridade do seu crédito, como o protesto para a eficácia do crédito contra abalistas e endossantes e o protesto para entrada no concurso de credores. Tem de interpelar, se é o caso, e propor a ação que lhe caiba, ou a mais adequada no caso. As medidas cautelares e executivas não podem ser menosprezadas.

\footnotetext{
${ }^{19}$ TRABUCCHI, Alberto. Instituzioni di Diritto Civile. Padova: CEDAM. 1990, p. 49.

${ }^{20}$ PERLINGIERI, Pietro. Perfis do direito civil: Introdução ao Direito Civil Constitucional. Trad. Maria Cristina de Cicco. Rio de Janeiro: Renovar, 1997, p. 128.
} 
Cresce de ponto a importância do ônus se foi previsto o risco de evento catastrófico, ou de revogação, ou de resolução ou resilição."21

Não parece haver motivo para que o conceito de ônus seja reduzido a um termo sinônimo de encargo. Isto porque o próprio ordenamento jurídico o emprega em contextos que nada se assemelham a uma imposição constante de um negócio jurídico gratuito. Exemplificativamente, cita-se o ônus da prova, imposto, em regra, à parte que alega um fato. Trata-se, muito sinteticamente, de uma disposição que limita o direito da parte devido à ausência de comprovação de um determinado fato no processo.

Ao menos em relação à sua estrutura, parece ser o ônus a figura que melhor reflete as características essenciais do dever do credor de mitigar o próprio dano. Contudo, tal definição não soluciona a ausência de uma fonte normativa para sua aplicabilidade no Brasil.

Analisa-se, portanto, a questão à luz dos deveres anexos da boa-fé objetiva, os quais, como se viu, informam a conduta das partes embora não sejam expressamente previstas no ordenamento jurídico. No último século, observou-se uma profunda alteração no direito civil, com a superação da análise meramente formal de conceitos como igualdade e justiça. Restou superado o modelo clássico, caracterizado pela total autonomia das partes tanto na estipulação dos termos do contrato, quanto em sua conduta, a qual era exclusivamente limitada pelas imposições expressas do contrato ou da lei.

Sobre essas transformações discorre Menezes Cordeiro:

“A primeira codificação, bem como a própria segunda, correspondiam a um modelo liberal clássico em que o Direito, confiando em absoluto no jogo livre das vontades individuais, numa liberdade entendida, tal como a igualdade, em sentido formal, abdicavam de nodo voluntário, de intervenções nos clausulados negociais. Este estado de coisas era reforçado por uma reação pendular aos entraves que as regulamentações complexas dos regimes pré-liberais haviam colocado à contratação livre e que se revelara nociva à revolução industrial. Nesse cenário, o juiz limitava-se a conferir a legalidade formal dos contratos e a

${ }^{21}$ MIRANDA, Pontes de. Tratado de Direito Privado: Parte Especial. Tomo XLVI, Direito das Obrigações; Seguros. Atualizado por MIRAGEM, Bruno. São Paulo: Editora Revista dos Tribunais, 2012, p. 144. 
sua correspondência com a vontade inicial das partes, indiferentes por ofício, à justeza material dos arranjos de interesses por eles prosseguidos.

O funcionamento de livre da autonomia privada, mesmo em períodos históricos anteriores onde esse princípio não ocupava, no sistema jurídicoprivado, o papel primordial que lhe atribuiu o liberalismo, sempre conduzira a injustiças potenciais. Elas não suscitaram problemas, enquanto não encontraram pela frente uma cultura que, com projecções jurídicas, começou a encarar, como colectivo - e logo com uma vocação emanente para juridicidade - um trama que em si ,relevaria de uma problemática individual. O catalisar, em grupos sociais de extensão crescente, de problemas postos pela contração livre, obrigou ao perguntar pela efectividade da autonomia privada. Se, formalmente, ela se contenta com a inexistência de entraves ao seu desenvolvimento, de facto, ela requer a possibilidade de opção efectiva, aquando da celebração. Tal possibilidade pode ser frustrada pela ignorância do contratante, pela sua dependência econômica ou outra, por situações de monopólio, pela necessidade impreterível de contratar de imediato ou, simplesmente, por a contraparte se recusar a alterar a proposta ou a contraproposta que tenha formulado.,"22

\section{Sobrepondo-se à antiga ótica estritamente liberal, surgiu o princípio}

da boa-fé objetiva. Entre suas funções, destaca-se, por sua relevância para este trabalho, sua função criadora de deveres anexos de conduta. Assim, da boa-fé, um padrão de conduta objetivo - portanto extrínseco às partes —, surgem os seus deveres instrumentais, que, mesmo não previstos expressamente na lei ou no contrato, obrigam às partes:

"Embora não se possa, como alertamos acima, apresentar uma 'listagem taxativa' dos deveres instrumentais, o estágio da doutrina e da jurisprudência já permite sinalizar dois grandes tipos ou grupos. A distinção opera entre os que têm um fim marcadamente positivo e os que visam proteger a contraparte dos riscos de danos na sua pessoa e no seu patrimônio, sendo, então, denominados deveres de proteção .

Exemplificativamente, constituem deveres instrumentais (positivos e de proteção) os deveres de lealdade, de cuidado, previdência e segurança; de aviso e esclarecimento; de informação; de consideração com os legítimos interesses do parceiro contratual; de proteção ou tutela com a pessoa e o patrimônio da contraparte de não aguardar a situação do parceiro contratual; de evitar ou diminuir os riscos; de abstenção de condutas que possam pôr em risco o programa contratual; de omissão e de segredo, em certas hipóteses, deveres que podem anteceder o contrato, na chamada fase pré-contratual, ou mesmo prolongar-se findo o negócio, hipótese da responsabilidade pós-contratual, como já vinha apontando a jurisprudência esclarecida.

(...)

Assim como ocorre a criação de deveres, pode ainda verificar-se, pela incidência da boa-fé objetiva, a limitação do exercício de direitos subjetivos ou de direitos formativos.

[...] vedando a contrariedade da conduta contratual, hipótese designada pela expressão tu quoque, ou ainda carreando à antiga fattispecie do abuso de

22 CORDEIRO, António Manuel da Rocha e Menezes. Da Boa Fé no Direito Civil. Vol. I, Coimbra: Almedina, 1984, pp. 652-653. 
direito uma conotação objetiva, assim como procede, agora, o art. 187 do Código Civil.

Estes deveres e limitações não são passíveis de definição a priori, porque, notadamente na relação obrigacional derivada de contrato, são os que resultarão necessários para a realização do 'programa contratual' (entendido no aspecto objetivo e econômico-social) concretamente considerado.

Portanto, sua especificação depende de cada contrato, à vista da sua relação econômica de base, afirmando Ruy Rosado de Aguiar que a boa-fé, 'implica a criação de uma norma para o caso de acordo com os dados objetivos que ele mesmo apresenta, atendendo à realidade social e econômica em que o contrato opera, ainda que isto o leve para fora do círculo da vontade'.

Em suma, em paralelo aos deveres derivados do exercício da autonomia privada e daqueles especificamente cominados na lei, os deveres decorrentes da boa-fé, concretizados por via da atividade jurisdicional no campo de função demarcado pela relação obrigacional, sinalizam o adequado adimplemento, apontando, correspectivamente, às hipóteses de inadimplemento, cujo conceito resta, assim, correspondentemente alargado, pois pode ser ocasionado não só pela quebra dos deveres de prestação como pela violação dos deveres instrumentais e, de modo especial, dos deveres de proteção.

Por esta via compreende-se a íntima ligação ente o adimplemento (e, reversamente, o inadimplemento) e os deveres e limitações impostos pela boa-fé, considerada em sua feição objetiva. Esta, na medida em que implica a efetiva prossecução do fim da obrigação -isto é, o adimplemento com satisfação ‘complementa as formulações, por vezes lacônicas, dos vínculos creditícios', ao provocar, para ambos os integrantes da relação jurídica, a já aludida assunção de deveres instrumentais e ao impor, por vezes, limitações a direitos subjetivos e poderes formativos." ${ }^{23}$

Pietro Perlingieri, um dos mais aclamados autores civilistas a tratarem da boa-fé, considerado pioneiro no tema, já apontava para a criação de obrigações impostas ao próprio credor, as quais, guardadas as devidas proporções, se assemelham, em seu espírito e propósito, ao dever de mitigar o dano:

“(...) a cooperação, e um determinado modo de ser, substitui a subordinação e o credor se torna titular de obrigações genéricas ou específicas de cooperação ao adimplemento do devedor." ${ }^{, 24}$

Inegavelmente, o dever de mitigar os próprios danos parece enquadrar-se dentre esses deveres de boa-fé, pois desempenha incontestável padrão de conduta imposto ao credor da responsabilidade civil. Basicamente, consiste na regra de que o credor não pode permanecer inerte

\footnotetext{
${ }^{23}$ TEIXEIRA, Sálvio de Figueiredo (Org.). Comentários ao Novo Código Civil. Rio de Janeiro: Forense, 2003, pp. 1-43.

${ }^{24}$ PERLINGIERI, Pietro. op. cit., pp. 212.
} 
em relação ao seu próprio dano, devendo tomar atitudes razoáveis para evitar o agravamento de seu prejuízo. Trata-se, portanto, de um dever (mais propriamente definido como ônus, como visto acima), que impõe ao credor uma atuação proativa no sentido de evitar o agravamento de seu próprio prejuízo, respeitando-se, é claro, a razoabilidade de tais medidas.

O dever de mitigação diferencia-se, ainda, das limitações a exercício de direito decorrentes da boa-fé objetiva. Tome-se, por exemplo, a supressio, definida por Menezes Cordeiro como "uma forma de tutela da confiança do beneficiário, perante a inacção do titular do direito" 25 . Ao contrário do dever de mitigar o dano, há um dever imposto a uma das partes, criado a partir de sua inércia em relação a um direito, que confere à outra um verdadeiro direito de ver respeitada a legítima expectativa que viu nascer em seu benefício. Um eventual descumprimento da situação criada pode levar a uma violação positiva do contrato, pois a legítima expectativa da parte é passível de tutela, como vimos na lição de Menezes Cordeiro.

No caso do dever de mitigar, como já dito, não é conferido ao devedor qualquer direito ou mesmo expectativa de que a outra parte mitigue seus próprios danos. Todos os efeitos de tal dever são sentidos exclusivamente pelo credor, que vê nascer um verdadeiro filtro à sua pretensão indenizatória, restando esta limitada aos danos que não poderia, razoavelmente, evitar. É como se fosse realizado um segundo juízo de merecimento da tutela, posterior à análise do an debeatur, operando-se, exclusivamente na apuração do quantum debeatur e feito com base no comportamento do credor diante do agravamento de seu próprio dano.

\footnotetext{
${ }^{25}$ CORDEIRO, António Manuel da Rocha e Menezes. Tratado de direito civil português: direito das obrigações, cumprimento e não cumprimento, transmissão modificação e extinção, garantias. Coimbra: Almedina, 2010. vol. II. Ainda segundo o autor: "o não exercício prolongado estará na base quer da situação de confiança, quer da justificação para ela. Ele deverá, para ser relevante, reunir elementos circundantes que permitam a uma pessoa normal, colocada na posição do beneficiário concreto, desenvolver a crença legítima de que a posição em causa não mais será exercida. O investimento de confiança traduzirá o facto de, mercê da confiança criada, o beneficiário não dever ser desamparado, sob pena de sofrer danos dificilmente reparáveis ou compensáveis. Finalmente: tudo isso será imputável ao não exercente, no sentido de ser social e eticamente explicável pela sua inacção. Não se exige culpa: apenas uma imputação razoavelmente objectiva". op. cit., p. 324.
} 
Além disso, é incompatível com a correta noção do conceito de mitigação de danos que de seu descumprimento possa se extrair qualquer responsabilidade para o credor. Não se trata de uma compensação entre a indenização devida pela parte inadimplente com outra decorrente do descumprimento do dever de mitigar, mas de uma limitação no exercício de seu direito de cobrar a indenização.

Por todas essas razões, conclui-se que a figura que mais precisamente corresponde ao dever de mitigar os danos é a do ônus. No entanto, a fonte de sua aplicação no Brasil, tal qual ocorre com os deveres anexos acima referidos, deve ser a boa-fé objetiva (Código Civil, art. 422). Ou seja, embora não se discuta que o dever de mitigar deve ser visto como uma expressão da boa-fé objetiva, há de serem respeitadas suas particularidades, sob pena de se criar (e, como se verá quando da análise dos precedentes nacionais, parece que já se criou), um instituto que nada de novo incorpora ao direito brasileiro, uma vez que aplicado em situações que já poderiam ser resolvidas de outras formas com menos arranhaduras às tradicionais lições de direito civil. Respeitar sua função e sua estrutura, certamente, é ainda mais importante do que definir, com absoluta rigidez e à luz dos conceitos jurídicos já existentes, qual seria a sua natureza jurídica.

\subsubsection{Razoabilidade}

O dever do credor de mitigar seu próprio dano tem por pressuposto a existência de um inadimplemento contratual - embora admita-se sua aplicação também no âmbito da responsabilidade civil aquiliana ${ }^{26}-$, o qual pode, de forma razoável, ser mitigado pelo credor. O ponto que parece central do instituto, portanto, é a definição de conduta razoável.

De forma até mesmo similar à regra extraída do excerto transcrito do julgamento do caso British Westinghouse Eletric \& Manufactruing Co Ltd.

\footnotetext{
${ }^{26}$ PEIXOTO Alessandra Cristina Tufvesson, Responsabilidade extracontratual - Algumas considerações sobre a participação da vítima na quantificação da indenização. Revista da EMERJ, n.44, Rio de Janeiro, 2008, pp. 135-136.
} 
Contra a Underground Eletric Railways Co of London Ltd., o art. 77 da CISG definiu que o credor deve "tomar as medidas que forem razoáveis, de acordo com as circunstâncias, para diminuir os prejuízos resultantes do descumprimento, incluídos os lucros cessantes". Como deixa claro o teor do artigo, a análise da razoabilidade da medida deve ser feita caso a caso, levando em consideração a real possibilidade de o dano ter sido mitigado naquela hipótese específica.

Entretanto, o conceito de razoabilidade não se limita a definir se a parte poderia tomar alguma providência nas circunstâncias, de modo a mitigar seus danos. Define ele, também, a forma como a parte deverá cumprir tal imposição. Ou seja, não se trata, meramente, da análise se havia outra medida que poderia ser tomada, mas sim do exame da razoabilidade desta medida.

Novamente recorrendo-se ao caso British Westinghouse Eletric \& Manufactruing Co Ltd. contra a Underground Eletric Railways Co of London Ltd., o julgado da Câmara de Apelação (instância inferior à Câmara dos Lordes), em seu fundamento, pondera a seguinte situação:

"If a man who has taken a third class ticket from London to the north by one of the great train companies is by the negligence of that company damaged by their breach of contract to convey him, and he, to reduce the damages, goes to another of the great train companies and takes a ticket by the next train on that line, and is thus enabled to reach his destination by the contract time, but cannot travel by that train unless he takes a first class ticket, his damages may well be the whole of the sum he has to pay for that ticket, although the result is that he has enjoyed a greater luxury of travel."

Fica claro que o conceito de razoabilidade é que determinará o limite até onde a parte pode ir na tentativa de mitigar seus danos. No exemplo dado, somente seria possível para o credor, frustrado em seu direito de viajar nos termos da passagem que adquiriu, viajar em um trem de outra companhia se o fizesse na primeira classe. Portanto, apesar da diferença de preço, não seria razoável esperar que ele simplesmente deixasse de viajar, e, com isso, provavelmente, permitisse que seus danos inflassem, simplesmente por não haver passagem de preço similar disponível. Neste 
caso, a transação substituta terá sido feita para mitigar o dano de forma razoável, e, por tal motivo, o credor poderá exigir do devedor o pagamento integral da indenização devida, que corresponderá a diferença entre os valores das duas passagens.

Em ao menos um julgado ${ }^{27}$, foi discutido se o fato dos bens terem se desvalorizado exponencialmente desde a celebração do contrato poderia ser invocado pelo credor como sendo um fato que afastaria a razoabilidade na revenda dos bens como uma medida de mitigação. No caso concreto, um comprador alemão adquiriu cisteína (mais conhecido por aqui como Ajinomoto) de uma vendedora chinesa. Entre o momento da compra e o recebimento pelo credor dos bens fora de especificação solicitada houve fortíssima desvalorização da cisteína no mercado. Como o credor, obviamente, somente pode revender os bens pelo preço de mercado no dia da segunda transação, o devedor alegou que ele teria vendido muito barato, e, portanto, não teria mitigado seus danos de forma razoável. No entanto, ao julgar a causa, o tribunal arbitral responsável decidiu em favor do credor, pois não se poderia exigir dele que lograsse obter um preço melhor do que o praticado pelo mercado no momento em que conseguiu os bens.

É importante ter em mente que a razoabilidade deve ser interpretada de forma a não se exigir do credor — que já sofre os efeitos do inadimplemento da outra parte - um comportamento fora dos padrões de seu negócio. Como adverte Komarov, o dever de mitigação não pode ser transformado em um fetiche:

"Along with this general idea, the following observation should be also taken into account: the party who ought to mitigate will not be held to an extraordinary standard of behavior. The extent to which there should have been mitigation is a question of fact, and the plaintiff must take steps consistent with demands for reasonable and prudent action. The plaintiff will not have to embark on a difficult and hazardous course of action, nor to act in such a way as to impair his commercial reputation. Also it is worth noting that, as suggested, one should not make a fetish of the doctrine of mitigation." 28

\footnotetext{
${ }^{27}$ CIETAC. Procedimento $\mathrm{n}^{\circ}$ CISG/2000/06, julgado em 7 de janeiro de 2000.

${ }^{28}$ KOMAROV, op. cit., pp. 41-42.
} 
Uma excelente definição do que deve ser considerado razoável para fins de mitigação de danos, a qual resume tudo quanto se disse neste subtópico, é extraída do Cooling System Case $^{29}$, em que se afirmou que: $a$ potential measure to mitigate damages is reasonable, if in good faith it could be expected under the circumstances.

\subsection{3 Ônus da Prova}

Outro tema que merece destaque é o ônus da prova em relação à alegação de descumprimento do dever de mitigar. Muito embora o dever de mitigar seja uma incumbência atribuída ao credor, o ônus de provar tal circunstância, ao menos na visão da maior parte dos autores, deve recair, a princípio, sobre o devedor:

"Arbitration practice unequivocally shows that, from a procedural point of view, reference to mitigation is ordinarily made by the respondent on whom rests the burden of proving that the claimant failed to mitigate avoidable damages by reasonable measures." 30

"As to mitigation, the rule should be as follows: the party, who argues that the injured party has not taken appropriate mitigation measures, bears the burden of proving this allegation.",31

Este entendimento é manifestado, por exemplo, no Metal Concentrate Case $^{32}$, que teve a CISG como lei aplicável. No aludido julgado se afirmou que:

“(...) the party who argues that the aggrieved party has not taken appropriate steps to prevent unnecessary damage from occurring which carries the burden of proof for his allegation in this regard. In this arbitration it has not been argued that there would have been any alternative course of action open for the [buyer] which would have produced a less costly outcome than the one actually chosen by the [buyer]."

\footnotetext{
${ }^{29}$ Oberster Gerichtshof (Austria), Caso no 7 Ob 301/01t, Viena. Julgado em 14/1/12.

${ }^{30}$ KOMAROV, op. cit., p. 49.

${ }^{31}$ SAIDOV, op. cit.

${ }^{32}$ ICC. Procedimento no 8574 julgado em Setembro de 1996.
} 
De fato, não seria razoável se exigir que o credor, ao formular sua demanda, tivesse de demonstrar que todas as medidas imagináveis para mitigar seu dano seriam irrazoáveis. No entanto, é controvertida a hipótese em que o credor toma medida para mitigar seu dano. Parece ser aceitável tanto a posição de que o ônus continua com o devedor, que deve provar que não se trata de uma forma razoável de mitigar o dano, demonstrando quais outras medidas poderia ter tomado o credor, como a posição contrária, segundo a qual o próprio credor, ao ajuizar a demanda, deveria demonstrar a razoabilidade da medida tomada. Neste ponto, Elizabeth Opie aponta para uma diferença na redação do art. 7.4.8 dos princípios do UNIDROIT $^{33}$ e o art. 77 da $\mathrm{CISG}^{34}$ :

"The non-performing party has to prove that the aggrieved party failed to comply with its obligation to mitigate its loss (including loss of profit) pursuant to Art. 77 CISG. As noted above, there are two elements separately provided for under Art. 7.4.8 UNIDROIT Principles: (i) the obligation to mitigate and (ii) the right to be compensated for reasonable expenses. Pursuant to Art. 7.4.8 UNIDROIT Principles, the burden of proof will rest on the non-performing party to demonstrate that the aggrieved party has failed to reduce the harm by taking reasonable steps. As it is the aggrieved party who will assert that the expenses incurred as part of its actions to mitigate harm were reasonable in the circumstances, then the burden on proving this will rest on the aggrieved party.

If the above comments on the breadth of the obligation to mitigate under Art. 77 CISG are accepted, then the onus would rest with the non-performing party under this Article in relation to both the loss and expenses incurred in mitigating that loss. That is, burden will not lie with the aggrieved party to prove that measures taken to mitigate expenses were reasonable. There is a rebuttable presumption which lies in favor of the aggrieved party." 35

É interessante a posição da autora australiana. No entanto, não se vislumbra qualquer diferença substancial entre ambos os artigos para que se

\footnotetext{
${ }^{33}$ (1) The non-performing party is not liable for harm suffered by the aggrieved party to the extent that the harm could have been reduced by the latter party's taking reasonable steps. (2) The aggrieved party is entitled to recover any expenses reasonably incurred in attempting to reduce the harm.

${ }^{34}$ A party who relies on a breach of contract must take such measures as are reasonable in the circumstances to mitigate the loss, including loss of profit, resulting from the breach. If he fails to take such measures, the party in breach may claim a reduction in the damages in the amount by which the loss should have been mitigated.

${ }^{35}$ OPIE, Elisabeth. Commentary on the manner in which the UNIDROIT Principles may be used to interpret or supplement Article 77 of the CISG. Disponível em http://www.cisg.law.pace.edu/cisg/principles/uni77.html\#eo28. Acesso em 29/10/13
} 
possa concordar com tal interpretação. Mais razoável parece ser manter o ônus da prova com o devedor em todos os casos, pois é ele quem deve pleitear uma redução no valor da indenização.

Esta discussão, aliás, perde um pouco sua relevância diante da constatação de que o juiz ou árbitro que se deparar com uma hipótese de mitigação pode reduzir o valor de indenização ex officio, é claro, desde que possua elementos suficientes para formar sua convicção a este respeito. Sobre o tema, recorra-se a um dos mais celebrados julgados envolvendo a aplicação do dever de mitigação, o Vine Wax Case ${ }^{36}$. Registre-se, na oportunidade, que o caso como um todo será mais detidamente analisado no capítulo em que se tratar da aplicação do art. 77 da CISG. Por ora, basta destacar aqui que a violação ao dever de mitigar o próprio dano foi reconhecido pela Corte Federal Alemã mesmo sem ter sido formalmente alegada pelo réu, pois as evidências nos autos apontavam que o credor, embora tenha adquirido produto que prejudicava suas plantações, não cessou sua utilização imediatamente após constatar o vício. O mesmo entendimento foi aplicado no Aluminium hydroxide Case $^{37}$. Como regra geral, portanto, conclui-se que o ônus da prova a princípio deve repousar sobre o devedor, admitindo-se, contudo, seu reconhecimento ex officio, se presentes elementos objetivos que possam levar o juiz a concluir pela existência de medidas razoáveis de mitigação disponíveis ao credor.

\footnotetext{
${ }^{36}$ Bundesgerichtshof. VIII ZR 121/98. Julgado em 24/3/99.

${ }^{37}$ Oberlandesgericht Köln. 18 U 121/97. Julgado em 21/8/97.
} 
2.1 Os Fundamentos da Aplicação do Dever de Mitigar no Brasil 2.2 Análise de Disposições Relacionadas do Código Civil 2.2.1 Outras Aplicações 2.3 Precedente Nacionais

\subsection{Os Fundamentos da Aplicação do Dever de Mitigar no Brasil}

No Brasil, ao menos até a incorporação da CISG, não havia previsão expressa de que o credor de indenização por responsabilidade civil deve mitigar seu próprio prejuízo, sob pena de ver reduzida a verba indenizatória a que terá direito, situação que perdurará em relação às obrigações domésticas. A bem da verdade, não há, ainda, na clássica doutrina nacional, grande destaque para o assunto. Igual desinteresse pela questão demonstrou o legislador, que, tanto no Código Civil de 1916 quanto no de 2002, omitiuse sobre eventual dever do credor de mitigar seus próprios danos.

O tema, contudo, ganhou destaque no Brasil há cerca de dez anos, quando Vera Maria Jacob de Fradera, que já havia se dedicado ao assunto, propôs à III Jornada de Direito Civil do Conselho da Justiça Federal o que viria a se tornar o enunciado $\mathrm{n}^{\circ} 169$, que ganhou a seguinte redação: o princípio da boa-fé objetiva deve levar o credor evitar o agravamento do próprio prejuízo.

Como se vê, não apenas foi admitido, pelo $\mathrm{CJF}$, que o direito brasileiro prevê o dever do credor de mitigar seu próprio dano, como foi consagrada a orientação de que a aplicabilidade do instituto decorre de sua incorporação à cláusula geral de boa-fé prevista no art. 422 do Código Civil - o que, como se verá, é criticado por alguns. Assim como os demais deveres corolários da boa-fé objetiva, entre os quais se incluem, por exemplo, os deveres de lealdade e informação, o dever de mitigar seus próprios danos seria uma expressão do padrão de conduta desejável.

Confirmando o que foi dito no item que tratou da natureza jurídica do instituto à luz do nosso direito, verifica-se que esta a posição foi 
acompanhada pela grande maioria dos autores nacionais que estudaram o tema:

- Vera Maria Jacob Fradera ${ }^{38}$ :

"Não cumprindo o dever de mitigar o próprio prejuízo, o credor poderá sofrer sanções, seja com base na proibição de venire contra factum proprium, seja em razão de ter incidido em abuso de direito, como ocorre em França.

No âmbito do direito brasileiro, existe o recurso à invocação da violação do princípio da boa fé objetiva, cuja natureza de cláusula geral permite um tratamento individualizado de cada caso, a partir de determinados elementos comuns: a prática de uma negligência, por parte do credor, ensejando um dano patrimonial, um comportamento conduzindo a um aumento do prejuízo, configurando, então, uma culpa, vizinha daquela de natureza delitual.

A consideração do dever de mitigar como dever anexo, justificaria, quando violado pelo credor, o pagamento de perdas e danos.

Como se trata de um dever e não de obrigação, contratualmente estipulada, a sua violação corresponde a uma culpa delitual.”

\section{- Flávio Tartuce ${ }^{39}$ :}

"Conceito também interessante relacionado com o princípio da boa-fé objetiva é a mitigação do próprio prejuízo ou, na expressão inglesa, duty to mitigate the loss. Sobre o tema, foi aprovado o Enunciado n. 169, na III Jornada de Direito Civil, com a seguinte redação: 'o princípio da boa-fé objetiva deve levar o credor a evitar o agravamento do próprio prejuízo'. A proposta, elaborada por Vera Maria Jacob Fradera, professora da Universidade Federal do Rio Grande do Sul, representa muito bem a natureza do dever de colaboração, presente em todas as fases contratuais. (...)

Pois bem, em casos envolvendo o duty to mitigate the loss, propõe Vera Jacob Fradera que o não-atendimento a tal dever traria como consequência sanções para o credor, principalmente a imputação de culpa próxima à culpa delitual, com o pagamento de eventuais perdas e danos, ou a redução do seu próprio crédito. É de se concordar com tal entendimento, sendo certo que fomos favoráveis à aprovação de enunciado quando da III Jornada de Direito Civil, realizada em dezembro de 2004. Na verdade o dever de mitigar o prejuízo constitui um dever anexo de conteúdo instigante, que convoca a comunidade jurídica para debate relativo ao alcance da boa-fé objetiva."

\section{- Alessandra Cristina Tufvesson Peixoto ${ }^{40}$ :}

\section{“2. DUTY TO MITIGATE THE LOSS}

Vista a relevância da vítima para o estabelecimento da indenização adequada, trato de instituto que vem sendo desenvolvido no direito estrangeiro e que

\footnotetext{
${ }^{38}$ FRADERA, Vera Maria Jacob de. Pode o credor ser instado a diminuir o próprio prejuízo? Revista Trimestral de Direito Civil no 19, p. 119.

${ }^{39}$ Flávio Tartuce, Função Social dos Contratos - do Código de Defesa do Consumidor ao Código Civil de 2002, $2^{\text {a }}$ ed., Método, São Paulo, 2007, pp. 209 e 211.

40 PEIXOTO, Alessandra Cristina Tufvesson. Responsabilidade extracontratual: Algumas considerações sobre a participação da vítima na quantificação da indenização. Revista da EMERJ, n.44, Rio de Janeiro, 2008, pp. 135-136.
} 
começa a ser estudado no direito brasileiro. Trata-se do duty to mitigate the loss, ou mitigação do prejuízo pelo próprio credor. O fundamento para esse dever está diretamente ligado ao dever de boa-fé que deve existir entre os contratantes e entres os indivíduos, em geral.

Tem-se como conceito de boa-fé o dever de agir, nas relações sociais, de acordo com certos padrões mínimos de conduta socialmente recomendados, de lealdade, correção ou lisura, aos quais correspondem expectativas legítimas das pessoas"

\section{- Paulo Nalin e Hugo Sirena ${ }^{41}$ :}

"O que se tem, portanto, é a noção de que o princípio do duty to mitigate the loss está intimamente ligado à noção de boa-fé, ainda mais quando ele se insere no contexto das relações contratuais, independentemente de serem elas internacionais ou não. E, aqui, faz-se necessário destacar a projeção do presente estudo em lançar luzes à análise da boa-fé na sua acepção objetiva, ou seja, o princípio tomado "numa ótica exterior ao declarante, na qual pouco importam as boas ou más intenções, sobressaindo-se os atos e manifestações em conformidade com padrões ético-jurídicos vigentes, correspondente à lealdade, ao comportamento das pessoas honestas, em oposição ao dolo e a fraude e em respeito aos interesse legítimos e às expectativas razoáveis dos parceiros contratuais'."

De fato, é evidente a convergência do princípio de que o credor deve mitigar seus próprios prejuízos aos preceitos da boa-fé objetiva. Como se sabe, a boa-fé objetiva, tão propagada em quase todos os estudos de direito civil hoje em dia, tem como pilares deveres como os de lealdade e cooperação entre as partes. Esta (dever decorrente da boa-fé objetiva), sem dúvida, a forma pela qual deve ser introduzido o dever no Brasil.

No entanto, propõe-se aqui levar a questão um pouco adiante, analisando, ainda, o fundamento econômico, por assim dizer, da incorporação do conceito ao ordenamento sob o ponto de vista de sua importância para a sociedade como um todo. O direito positivo brasileiro revela uma preferência evidente pelo cumprimento específico da obrigação em relação a sua resolução em perdas e danos. É esta a regra geral que estabelecida, por exemplo, nos arts. 461, caput e $\$ 1^{\circ}$ e 645 do Código de Processo Civil.

\footnotetext{
${ }^{41}$ NALIN, Paulo e SIRENA, Hugo. A Convenção de Viena de 1980 e a Sistemática Contratual Brasileira: A Recepção Principiológica do Duty to Mitigate the Loss. Revista Jurídica, no 422, p. 37.
} 
O principal fundamento dessa preferência é assegurar à decisão judicial a máxima eficácia possível, fazendo desparecer, tanto quanto for plausível, os efeitos do descumprimento da obrigação. Do mesmo modo, se pode extrair dessa opção legislativa, de forma implícita, o reconhecimento de que é mais desejável para a sociedade como um todo que os efeitos do contrato sejam vistos na prática ${ }^{42}$.

Um exemplo mais extremado pode facilitar a visualização do ponto que se pretende fazer aqui. Suponha-se que todos os contratos atualmente em vigor sejam sistematicamente descumpridos, mas, que, por meio de resolução em perdas e danos, todos os credores recuperem exatamente o valor que corresponderia ao cumprimento desses contratos. Mesmo que não haja prejuízo aos credores, há um evidente prejuízo para a sociedade como um todo, pois, fatalmente, surtirão efeitos negativos em relação à circulação de créditos e bens, muitos empregos direta ou indiretamente deixarão de ser gerados e aí por diante. É socialmente mais desejável, portanto, que os contratos sejam cumpridos.

Invertida a lógica, pode-se afirmar que a ocorrência de um dano decorrente de um inadimplemento é socialmente indesejada. Mais uma vez valendo-se do absurdo exemplo acima, suponha-se que todos os credores que viram suas respectivas contrapartes inadimplirem suas obrigações poderiam, por meio de transações substitutas, assegurar o mesmo resultado prático que ocorreria se devidamente cumpridos os contratos, sem que isso demandasse qualquer medida irrazoável ou fora da condução regular de seus negócios. Isto preservaria as consequências benéficas e indiretas dos contratos para a coletividade, sem prejudicar o credor nem agravar a posição do devedor. Não por outro motivo, já existem autores que, embora

\footnotetext{
42 "Tamanha é a importância dos contratos como fato econômico, que sua disciplina jurídica constitui a estereotipação do regime a que se subordina a economia de qualquer comunidade. A função econômico-social do contrato foi reconhecida, ultimamente, como a razão determinante de sua proteção jurídica. Sustenta-se que o Direito intervém, tutelando determinado contrato, devido à sua função econômico-social. Em consequência, os contratos que regulam interesses sem utilidade social, fúteis ou improdutivos, não merecem proteção jurídica. Merecem-na apenas os que têm função econômico-social reconhecidamente útil. A teoria foi consagrada no Código Civil italiano, conquanto encontre opositores." (GOMES, Orlando. Contratos. 24 edição. Rio de Janeiro: Forense. 2001. p. 20)
} 
timidamente e sem tecer maiores considerações sobre o tema, afirmam que "the obligation to avoid where possible the consequences of a wrong implements a public policy against waste" ${ }^{43}$

Conclui-se, portanto, que a mitigação dos danos pelo devedor, a qual, ao menos no Brasil, decorre da boa-fé objetiva, possui também um relevante aspecto social, fazendo com que a economia como um todo deixe de ser exposta aos efeitos negativos do inadimplemento contratual quando isto seria evitável por uma ação razoável do credor. Como esta conduta nem sempre será voluntariamente tomada pelo credor, é necessário que se estipule tal dever, cominando-se ao seu descumprimento a perda do direito de indenização sobre o montante evitável. Ao mesmo tempo, é fundamental que se tenha por indenizável os gastos do credor ao mitigar seu próprio dano, desde que o faça de forma razoável.

\subsection{Análise de Disposições Relacionadas do Código Civil}

A posição de que a aplicação do dever do credor de mitigar os próprios danos decorre do art. 422 do Código Civil, ou seja, da boa-fé objetiva, embora predominante entre os estudiosos do tema, não é unânime na doutrina. Há nessa interpretação, de fato, certa presunção de que o Código Civil apresenta uma lacuna quanto ao tema. Antes de fazer tal presunção, é necessário examinar os artigos já previstos em nosso direito positivo, os quais servem de base para solucionar alguns dos casos que eventualmente poderiam ser resolvidos pela aplicação do princípio do dever de mitigação do próprio dano.

Ao criticar a posição de Fradera, que, segundo ele, parte da equivocada premissa de que há lacuna no ordenamento jurídico brasileiro a este respeito, Daniel Pires Novais Dias, cita alguns exemplos de normas do Código Civil brasileiro que, em sua visão, regulariam a hipótese do credor inerte em relação à mitigação dos prejuízos experimentados por culpa do

\footnotetext{
${ }^{43}$ MCMAHON, John. Drafting CISG Contracts and Documents and Compliance Tips for Traders. Disponível em http://cisgw3.law.pace.edu/cisg/contracts.html\#a77. Acesso em 19/10/13.
} 
devedor. Segundo ele, não haveria, no ordenamento jurídico nacional, qualquer lacuna que justificasse a recepção desse instituto jurídico.

O primeiro exemplo fornecido pelo autor é do art. 402 do Código Civil, que dispõe que "[s]alvo as exceções expressamente previstas em lei, as perdas e danos devidas ao credor abrangem, além do que ele efetivamente perdeu, o que razoavelmente deixou de lucrar". Extrai-se do referido artigo, que são indenizáveis, no direito brasileiro, tanto os danos emergentes quanto os lucros cessantes. Estes últimos, que como a própria lei define, constituem aquilo que a parte lesada "razoavelmente deixou de lucrar", são analisados por meio do critério da probabilidade objetiva. Não se exige a certeza inabalável de que o credor teria algum ganho, tampouco se permite a reparação do dano com base em mera possibilidade. Ou seja, não é qualquer valor que o credor deixou de auferir após o inadimplemento contratual que será indenizável, mas apenas aqueles que no curso normal de seus negócios ele receberia.

Segundo Daniel Pires Novais Dias, a análise da razoabilidade dos lucros cessantes envolve perquirir a conduta da parte lesada após o inadimplemento do contrato. Se ela, por exemplo, deixa de remediar prontamente um dano que vem ocorrendo, ainda que resultante da conduta da outra parte, não será razoável a perda de seu lucro, e, portanto, não será indenizável seu dano:

“(...) um fato nem sempre salientado é de que a conduta do credor inadimplido insere-se nesta análise da normalidade no desenvolvimento dos acontecimentos após o não cumprimento da obrigação. Se, por exemplo, o credor inadimplido se recusa injustificadamente a adotar medida que evitar ou reduziria a perda de lucro, esta perda não se inclui nas perdas e danos, por tratar-se, segundo o art. 402 do CC/2002, de montante que irrazoavelmente deixou de lucrar." 44

Para reforçar sua posição, o autor se vale de uma passagem de Aguiar Dias, que, ao comentar o art. 1.059 do Código Civil de 1916, de

\footnotetext{
${ }^{44}$ DIAS, Daniel Pires Novais. Op. cit. pp. 696-697.
} 
redação essencialmente idêntica ao atual art. 402, assim tratou da análise da razoabilidade dos lucros cessantes:

“(...) como lucro cessante não podem ser considerados os resultados artificiosamente criados pelo prejudicado. A este não é lícito, por exemplo, por sua inércia ou demora em mandar reparar o objeto ou bem danificado, agravar a situação do responsável, aumentando a indenização dos lucros cessantes. Os prejuízos devem ser calculados de acordo com o tempo realmente necessário para concluir as reparações e assim fazer desaparecer as consequências daí decorrentes, como, por exemplo, a não percepção de aluguel, por sua forçada inatividade." 45

Considerava, portanto, o autor, que, dentro da definição de razoabilidade dos lucros cessantes, encontra-se a imposição ao credor de uma obrigação de mitigar os próprios danos, não podendo ele cobrar do devedor prejuízo que poderia ter evitado. De fato, ao menos pelo teor da lição de Aguiar Dias, parece ser possível enquadrar na hipótese do art. 402 boa parte das situações em que se aplica o dever de mitigação. No entanto, algumas críticas podem ser feitas à proposição de Daniel Pires Novais Dias de que este artigo, bem como os outros dois de que se cuidará mais adiante, tornariam inútil o instituto da mitigação no Brasil.

Primeiramente, registre-se que o resultado da aplicação do art. 402 ao invés do art. 422 seria exatamente o mesmo: em ambos os casos, deixaria o credor de receber a indenização correspondente ao dano que poderia ter evitado com uma conduta razoável.

Ademais, em que pese a valorosa lição de Aguiar Dias, não se pode ter como pacífica a noção de que o conceito de razoabilidade dos lucros cessantes afasta os danos não mitigados. $\mathrm{O}$ conceito de razoabilidade dos lucros cessantes parece ser muito mais ligado ao grau de certeza quanto à ocorrência do lucro futuro do que uma forma de se interpretar a conduta do credor em relação a eles.

Por outro lado, deve ser criticada a posição do autor de que somente uma lacuna no ordenamento jurídico justificaria a aplicação do dever de mitigação pelo art. 422. Toda a lógica da boa-fé objetiva seria invertida se

\footnotetext{
${ }^{45}$ Idem, p. 607.
} 
fosse verdadeira tal premissa. A boa-fé objetiva é um padrão de conduta que deve ser mantido pelas partes em todo momento. Muito distante de uma mera norma de aplicação subsidiária, deve ela informar a interpretação de todos os demais artigos, não se podendo admitir o exercício de direito de forma contrária aos deveres da boa-fé. Mesmo que houvesse norma regulamentando a matéria, ainda seria possível aplicar-se, conjuntamente, o art. 422 para se exigir que o exercício de direito se dê de forma consonante com a boa-fé. Não há como deixar de se observar que inexiste distinção prática entre se interpretar o art. 402 de forma a excluir do conceito de lucros cessantes razoáveis os danos não mitigados pelo credor ou fazer exatamente o mesmo em relação ao art. 422. A verdade é que nenhum dos dois artigos expressamente impõe ao credor tal obrigação. No entanto, o art. 422 foi propositadamente formulado como um conceito aberto, sujeito à recepção de novos padrões de conduta. Em outras palavras, ao invés de se afirmar, por meio de uma interpretação bastante ampliativa, que o art. 402 já afastaria a indenização de danos que o credor poderia evitar, parece bem mais razoável a afirmativa de que o credor possui um dever decorrente da boa fé objetiva de mitigar seu próprio prejuízo.

O segundo artigo mencionado pelo autor é o art. 403 do Código Civil, que dispõe que "[a]inda que a inexecução resulte de dolo do devedor, as perdas e danos só incluem os prejuízos efetivos e os lucros cessantes por efeito dela direto e imediato, sem prejuízo do disposto na lei processual." Aliado ao art. 944 do Código Civil ${ }^{46}$, este artigo estabelece a extensão do dano como o limite para a indenização no sistema nacional de responsabilidade civil.

A crítica feita pelo autor, desta vez, é de que o dano que o credor poderia mitigar não seria direto e imediato, e, por isso, escaparia ao critério estabelecido pelo referido artigo.

\footnotetext{
46 “Art. 944. A indenização mede-se pela extensão do dano.

Parágrafo único. Se houver excessiva desproporção entre a gravidade da culpa e o dano, poderá o juiz reduzir, eqüitativamente, a indenização".
} 
Aqui deve ser destacado um aparente equívoco na formulação da crítica, repetido em relação ao art. 945, adiante comentado. É que a mitigação de danos, naturalmente, pressupõe que os danos tenham sido causados, direta e imediatamente, pelo devedor. Só assim é que se estará diante de uma hipótese de aplicação do instituto da mitigação de danos pelo credor. Ao deixar de mitigar um dano, o credor não se torna o responsável direto e imediato por sua ocorrência. Este será sempre o devedor, pois é inexecução contratual - e não a inércia do credor em mitigar seu dano - a fonte direta e imediata do dano. Por exemplo, suponha-se que a parte $\mathrm{X}$ adquiriu alimentos perecíveis da parte $\mathrm{Y}$ por dez mil reais, e esta, descumprindo os termos do contrato, entregou mercadoria fora das especificações exigidas, não sendo possível devolver os bens ao vendedor antes que eles pereçam. Indubitavelmente, a inexecução do contrato é a causa direta e imediata de um dano de, pelo menos, dez mil reais. Suponhase agora que o vendedor alegue como argumento eventual de defesa que o dano poderia ter sido mitigado pelo comprador, sem esforço descomunal, por meio de uma revenda a um dos muitos compradores do produto efetivamente entregue. Ainda que venha a ser constatada a procedência do argumento do vendedor, tal fato não modificaria a causa direta e imediata do dano: a inexecução do contrato pelo vendedor.

O que o art. 403 exclui das perdas e danos que são devidas ao credor são os prejuízos não diretamente relacionados a uma inexecução do devedor, como os danos indiretos. O exemplo citado pelo referido autor é o clássico caso da vaca doente elaborado por Robert Joseph Pothier. Um vendedor dolosamente entregou a um fazendeiro uma vaca que sabia sofrer de doença contagiosa. A vaca acaba por contaminar todo o rebanho do comprador que fica sem nenhum animal para arar sua terra. Sem conseguir honrar suas dívidas, ele tem sua propriedade sequestrada e seus bens são vendidos a preço vil. Neste exemplo, segundo o célebre jurista francês, o vendedor é responsável pelo dano relacionado à própria vaca vendida, bem como pela morte de todas as demais. No entanto, não haveria relação de 
necessariedade entre sua conduta e a falta de cultivo da terra, pois o comprador poderia, por outros modos - subarrendamentos, locação, etc. - impedir que a terreno permanecesse inutilizado.

No entanto, a aplicação do referido art. 403 não parece suficiente para se alcançar a conclusão a que chegou Pothier há três séculos. Em primeiro lugar, como já observado, o artigo cuida de perdas e danos direta e imediatamente ligados à inexecução do contrato. Neste caso, obviamente, quem inadimpliu o contrato foi o vendedor, agindo, inclusive, de forma dolosa. Não há qualquer concorrência de culpa do comprador na inexecução, tanto é que sequer se cogita de sua corresponsabilidade pelos danos causados pelas perdas dos animais.

O ponto fundamental, entretanto, é que, sem que se admita que existe um dever do comprador de mitigar seu próprio prejuízo, não é possível chegar à mesma conclusão obtida pelo ilustre autor francês. Com o perdão de Agostinho Alvim, segundo quem não poderá o comprador cobrar do dever os prejuízos relacionados à perda da terra, pois, apesar de não estar obrigado a tomar qualquer providência para mitigar seu próprio dano, existe "um fato, imputável a ele, e isso basta" ${ }^{47}$, se não existe dever do comprador de impedir a produção de danos ao seu próprio patrimônio, é forçoso reconhecer que a cadeia de eventos aponta para a responsabilidade do devedor também pela perda da terra. Afinal, a perda da propriedade decorreu da ausência de animais que foi causada pelo contágio provocado pela vaca doente dolosamente entregue pelo devedor. Considerando-se, é claro, que a perda da propriedade tenha, de fato, sido diretamente resultante da falta de animais - o que pode ser verificado, por exemplo, pelo intervalo de tempo entre um evento e o outro - não há, a princípio, qualquer conduta, ativa ou omissiva, do comprador que interrompa o nexo de causalidade. Em outras palavras, analisando-se a questão exclusivamente a luz do texto do art. 403, sem que se reconheça um dever do comprador de mitigar seu próprio dano, não parece possível outra conclusão senão a de

${ }^{47}$ ALVIM, Agostinho apud DIAS, Daniel Pires Novais, p. 699. 
que o vendedor deve responder por todos os danos experimentados pelo comprador.

No entanto, não se afiguraria razoável tal solução. O que se espera de um negociante sério, efetivamente preocupado com seus negócios, é que tome providências para impedir um resultado tão desastroso quanto a perda de suas terras. Por esse motivo, é quase intuitivo se afirmar que o comprador não poderia permanecer totalmente inerte e ainda assim receber o montante total da indenização, ainda que todos os danos sejam direta e imediatamente causados pela inexecução do devedor. Muito embora tal conceito ainda não existisse em sua época, a solução dada por Pothier é um excelente exemplo de uma solução de um caso com base no dever da parte inocente de mitigar seu próprio dano, sob pena de não poder cobra-lo integralmente do devedor.

O terceiro artigo que Daniel Pires Novais Dias afirma regular as hipóteses em que o credor permanece inerte face a um dano próprio é o art. 945 do Código Civil. O que se extrai do referido artigo, é o que convencionou-se denominar "culpa concorrente da vítima". Diz o artigo que: "[s]e a vítima tiver concorrido culposamente para o evento danoso, a sua indenização será fixada tendo-se em conta a gravidade de sua culpa em confronto com a do autor do dano".

Como se vê de sua redação, o art. 945 regula a participação da vítima no "evento danoso". Em outras palavras, à semelhança do que se disse em relação ao art. 403, o autor pretende aplicar uma norma que regula um momento anterior à produção de danos, o evento danoso, para regular as consequências da omissão do credor após a ocorrência dos prejuízos.

Isto fica claro no próprio exemplo utilizado pelo autor, que, valendose de uma situação hipotética na qual a vítima se recusa a se submeter a tratamento médico, e, com isso, agrava o próprio dano, afirma que seria o art. 945 que regularia a situação, fazendo, contudo, a ressalva de que o STF, desde os anos 50, considera aceitável a conduta de se recusar a se submeter a cirurgia. Claramente, o exemplo citado é de concorrência para o evento 
danoso, pois, caso não realize a cirurgia e venha a falecer, o credor terá dado causa, ao menos parcialmente ao evento danoso. Na hipótese aludida, o comportamento do credor influiu decisivamente na ocorrência do próprio evento danoso.

O autor, contudo, não ignora que o referido artigo trata apenas da atitude do credor até o momento do evento danoso. Como se vê do seguinte trecho, ele reconhece tal limitação expressa no artigo, optando, no entanto, por realizar uma extensão de seu significado:

"Por outro lado, analisando o texto do art. 945 do CC/2002, é possível afirmar que a expressão "evento danoso" dá a impressão de que o dispositivo restringe-se às situações em que a conduta da vítima contribui para o fato danoso, não se aplicando aos casos em que a sua contribuição se dá somente em relação à sua extensão (agravamento do dano). Por exemplo: um motociclista que imprudentemente trafega na contramão e é atropelado por veículo conduzido em velocidade acima do limite máximo permitido. Neste caso, o motociclista contribuiu para a ocorrência da colisão (evento danoso) e o art. 945 do CC/2002 indubitavelmente incide para fins de fixação da indenização. Agora, se, diferentemente, o motociclista está parado no sinal vermelho sem capacete e é atropelado, ele não contribuiu para o atropelamento (evento danoso), mas a sua conduta (culposa) de estar sem capacete poderá ter contribuído para a maior extensão (agravamento) dos danos sofridos. E por este dano agravado, decorrente da soma das condutas de ofensor e ofendido, deve ser levada em conta a conduta da vítima para fim de fixação da indenização. E qual o critério para a fixação da indenização? Tratando-se de culpa concorrente (para os danos agravados), naturalmente o da gravidade da culpa, previsto no art. 945 do CC/2002. Assim, não obstante a expressão legal 'evento danoso' não faz sentido excluir os casos de agravamento de dano por parte da vítima do âmbito de incidência do art. 945 do CC/2002. Tratam-se de casos em que as condutas do agente e da vítima funcionam como causa para o dano agravado, de maneira equivalente aos casos em que ambas as partes contribuem para $\mathrm{j}$ dano inicial, ou evento danoso. A expressão 'evento danoso' deve, portanto, ser entendida de maneira mais ampla, como dano.

Assim, segundo a orientação aqui adotada, a situação em que a vítima negligencia adotar conduta para evitar a produção ou o agravamento do próprio prejuízo é regulada pelo art. 945 do CC/2002, por tratar-se de caso de culpa concorrente da vítima e não culpa exclusiva, em relação aos danos agravados." ${ }^{48}$

Não se nega aqui que a posição é aceitável até certo ponto, já que a noção de concorrência de condutas não é, exceto pelo momento de sua incidência, muito distante da ideia de que o credor deve mitigar seu próprio prejuízo. No entanto, mais uma vez parece pouco consistente a posição do

\footnotetext{
${ }^{48}$ DIAS, Daniel Pires Novais. Op.cit., p. 705.
} 
autor ao criticar a inclusão do referido conceito como um dever anexo aplicável com base no art. 422 — notoriamente um artigo de redação aberta justamente para que possa recepcionar os avanços doutrinários e jurisprudenciais quanto aos contornos da boa-fé objetiva - , e, ao mesmo tempo, propor uma abrupta ampliação dos termos expressos do art. 945, para que ele passe a regular, também, a atitude do credor em relação ao dano, uma vez consumado. Parece que o autor se inspirou no $\$ 254$ do BGB, mas, no aludido dispositivo, existe expressa previsão de que deixar de mitigar o dano importa em concorrência de conduta do credor, o que não há no nosso art. 945.

No entanto, o que é crucial para que se perceba o equívoco do autor é a suposta violação por ele vislumbrada ao art. 945 toda vez que um tribunal aplica a doutrina do dever de mitigação de danos. Segundo o autor, a consequência jurídica do credor deixar de mitigar seu dano não poderia ser o abatimento do valor do dano evitável, mas sim uma redução baseada no grau de culpa, ou reprovabilidade, da conduta do credor:

"Deve-se, no entanto, atentar que o art. 945 do CC/2002 resta violado quando os tribunais simplesmente excluem, como têm feito com base no duty to mitigate the loss, a indenização da vítima pelos danos que ela poderia ter evitado. Isto porque, uma vez que estas situações se incluem no art. 945 do CC/2002, a fixação da indenização pelos danos que poderiam ter sido evitados deve-se dar com base na gravidade da sua culpa em confronto com a do autor do dano.

(...)

6. O art. 945 do $\mathrm{CC} / 2002$ fala em 'se a vítima tiver concorrido culposamente para o evento danoso'. A culpa, conforme concepção normativa com que é atualmente entendida, corresponde a juízo de reprovação ou desvalor relativamente à conduta ilícita do agente. Naturalmente, uma conduta só pode ser censurada pelo direito se for contrária aos seus preceitos."

Prende-se o autor ao critério da gravidade da culpa do agente para afirmar que se a mitigação não é um dever da parte, não pode sua conduta omissiva ser tida por "culposa", e, logo, não poderia ela concorrer culposamente para o dano. Ou seja, com base no referido art. 945 vislumbra o autor uma suposta impossibilidade de redução da indenização devida, pois

\footnotetext{
${ }^{49}$ Idem, p. 705.
} 
a conduta de mitigar o próprio dano não é exigível, e, assim, a eventual inércia do credor não poderia ser tida como culposa.

Ignora o autor uma imprecisão técnica na redação do art. 945, já que, sabidamente, não é a gravidade da culpa do credor que determinará o valor em que será fixada a indenização. O credor pode, perfeitamente, agir dolosamente e dar causa a $1 \%$ do dano, sendo todo o restante do dano causado por não mais do que a conduta do devedor, e nem por isso sofrerá qualquer abatimento em sua indenização além do $1 \%$ do prejuízo a que deu causa. Conforme observa Gisela Sampaio da Cruz é o grau de participação (causalidade) no evento do danoso o critério que deve nortear a aplicação do art. 945, independente do grau de culpa:

"Na redação do artigo 945, ora comentado, torna-s a considerar a gravidade da culpa concorrente (no caso, da própria vítima) para determinar a participação na obrigação de indenizar, quando o melhor critério, conforme já demonstrado, seria o do nexo causal. Ao comentar tal dispositivo, já observava Aguiar Dias:

'No art. 947 [o autor refere-se ao art. 947 do Projeto que, quando aprovado, passou a corresponder ao art. 945 do Código Civil de 2002], volta-se a considerar a gravidade da culpa concorrente, para determinar a participação na obrigação de indenizar, quando o melhor e mais exato critério, na espécie, é o grau da causalidade. Não é o grau de culpa, mas o grau de participação na produção do evento danoso, reduzindo-se ou até excluindose a responsabilidade dos demais, que deve indicar a quem toca contribuir com a cota maior ou até com toda a indenização'.

Não obstante a lição de Aguiar Dias, muitos autores ainda confundem causalidade ('participação') com culpa:

'Muito embora vários julgados sigam o critério da partilha dos prejuízos em partes iguais (RT, 564/146, 575/136, 582/94, 585/127), bem estabeleceu este artigo que na fixação de indenização será levada em consideração a existência de culpas concorrentes, sob o critério da gravidade da culpa da vítima em comparação com a culpa do agente causador do dano, cabendo, portanto, ao juiz, na verificação do caso concreto, estimar o valor da indenização segundo o grau da participação culposa da vítima' (grifou-se).

Desta forma, mais apropriado seria se o legislador, em vez de se referir ao grau de culpa, tivesse feito menção à interferência da vítima no evento danoso. Aliás, o art. 945 concorre com o agente. Melhor seria se o legislador tivesse elaborado uma regra geral de distribuição do prejuízo entre os co-responsáveis pelo dano." ${ }^{, 50}$

\footnotetext{
${ }^{50}$ CRUZ, Gisela Sampaio da Cruz. O Problema do Nexo Causal na Responsabilidade Civil. Rio de Janeiro: Editora Renovar. 2005, pp. 342-344.
} 
Igualmente não deve prevalecer a interpretação de Daniel Pires Novais Dias, pois embora não seja juridicamente exigível pela outra parte, o dever de mitigar é uma limitação na conduta do credor, uma vez que atua como filtro da reparação do dano.

Em artigo publicado na revista brasileira de arbitragem, Edgardo Muñoz e Luiz Gustavo Meira Mozer já sustentavam a compatibilidade entre a CISG e o direito civil brasileiro, utilizando justamente o exemplo do recepção do dever de mitigação como um argumento favorável a esta harmonia entre os dois diplomas legais:

"De fato, o receio de que as disposições da CISG possam colidir com o princípio da função social do contrato, por exemplo, o qual inspirou o Código Civil Brasileiro de 2002 (CCB) (21), é injustificado. Em particular, as disposições que compreendem o referido princípio (22), base das regras que regulam os contratos de adesão (23), disparidade (24), e hardship (25) não entram em conflito com a CISG. Em relação aos contratos de adesão (26), a nulidade das cláusulas que proporcionam uma renúncia antecipada de qualquer direito derivado da natureza page '56' da negociação (27) evoca o tema da validade do contrato, o qual não é governado pela CISG (28). Por outro lado, apesar de o art. 424 do CCB (29) ser derrogado pela CISG (30), esta disposição coincide com o art. $8^{\circ}$ da CISG e com seus princípios inerentes à interpretação contratual - em particular a interpretatio contra proferentem (31). Em relação à disparidade, a CISG não aborda esta questão. A legislação doméstica aplicável deve decidir a sorte do contrato (32). Já em relação à situação de hardship, o art. 79 da CISG estabelece as mesmas condições dos arts. 478 a 480 do CCB.

De um modo geral, a CISG já imprimiu a sua influência na interpretação e construção da legislação nacional brasileira. Por exemplo, o Enunciado $n^{\circ} 169$ do Conselho da Justiça Federal (33), proposto pela Professora Véra Jacob de Fradera, tem sido a base para decisões de Tribunais brasileiros ao invocar o art. $77 \mathrm{da}$ CISG, segundo o qual a parte que invoca a quebra do contrato deve tomar medidas para mitigar o agravamento de seu próprio prejuízo (34). Por seu turno, o Enunciado $\mathrm{n}^{\circ} 409$ do Conselho da Justiça Federal, influenciado pelo art. $9^{\circ}$ da CISG e recentemente aprovado - também proposto pela Professora Véra Jacob de Fradera -, determina que as partes estão vinculadas por qualquer uso ou prática por elas acordado ou estabelecido - ou por qualquer prática estabelecida entre elas (35)." ${ }^{, 51}$

Conclui-se, portanto, em relação às críticas formuladas por Daniel Pires Novais Dias, que, embora tenha o autor apresentado preocupação legítima em aprofundar a discussão das normas já existentes no direito

\footnotetext{
${ }^{51}$ MUÑOZ, Edgard; MOZER, Luiz Gustavo Meira, A Adesão do Brasil à CISG: Consequências para o Comércio na China e América Latina. Revista Brasileira de Arbitragem no 34, 2012, pp. 5657.
} 
positivo pátrio, não há previsão legal que possa regular a situação do credor que permanece inerte diante de um dano que ele não tenha dado causa. A ausência de sobreposição de hipóteses de incidência não impediu, contudo, que o instituto fosse aplicado de forma deturpada, como se verá mais adiante.

\subsubsection{Outras Aplicações}

Além dos arts. 402, 403 e 944 do Código Civil, existem outras interessantes disposições dentro do mesmo diploma legal, que já foram citadas como exemplos do dever de mitigação do próprio dano no direito, como o art. $771^{52}$ :

"Sob pena de perder o direito à indenização, o segurado participará o sinistro ao segurador, tão logo que o saiba, e tomará as providências imediatas para minorar-lhe as consequências."

O referido artigo apresenta um dos ônus do segurado aos quais aludiu Pontes de Miranda em sua passagem transcrita no item em que se tratou da natureza jurídica do dever de mitigar. Conforme a interpretação atual desse dispositivo, somente no caso de efetivo agravamento do dano que não tenha sido comunicado é que o segurado perderá, parcialmente, o direito à indenização ${ }^{53}$. Claro que existe aqui algo próxima ao dever de mitigar os danos. No entanto, o exemplo não parece muito ilustrativo, pois a obrigação, neste caso, decorre muito mais da limitação de riscos típica do direito securitário do que de uma legítima mitigação de danos. Parece que os danos que se tenciona evitar com essa norma são os que seriam causados a todos os demais segurados caso o contratante ficasse inerte em relação ao seu dano e, ainda assim, este fosse integralmente coberto pela seguradora.

52 LEITE, Gisele. Roteiro sobre o princípio da boa fé objetiva. Disponível em http://www.egov.ufsc.br/portal/conteudo/leite-gisele-roteiro-sobre-o-princ\%C3\%ADpio-da-boaf\%C3\%A9-objetiva Acesso em 1/10/13.

${ }^{53}$ RODRIGUES NETO, Nelson in Alvim, Arruda e Alvim, Thereza (coord.) Comentários ao Código Civil Brasileiro. São Paulo: Editora Forense. 2004, p. 283. 
Além das hipóteses tradicionais, em que se aplica a teoria do dever de mitigar no âmbito da responsabilidade civil contratual, existe quem defenda sua aplicação também na esfera da responsabilidade aquiliana ${ }^{54}$. Assim, deveria o indivíduo lesado por ato ilícito extracontratual praticado por outra pessoa buscar minimizar seu prejuízo do mesmo modo que o contratante prejudicado pelo inadimplemento da outra parte, de forma a não ver reduzido o valor de sua indenização.

No entanto, a aplicação do referido instituto, que nasceu da responsabilidade contratual, poderia ser objeto de discussão, uma vez que, como se viu, predomina na doutrina e na jurisprudência brasileira o entendimento de que o fundamento de sua aplicação é o art. 422 do Código Civil, o qual impõe aos "contratantes" o dever de agir de acordo com a boafé objetiva. Em uma análise estritamente literal e precipitada, o referido artigo de fato poderia ser interpretado como um limitador do escopo de abrangência do dever de mitigação, restringindo-o às relações contratuais.

Contudo, não há sentido em delinear contornos tão estreitos ao instituto, uma vez que o objetivo de sua aplicação - impedir que uma parte se aproveite da outra para obter uma indenização maior da que resultaria caso ele adotasse uma postura razoável - serve para os dois tipo de responsabilidade civil. Menos razoável ainda seria limitar a boa-fé ao âmbito das relações contratuais, o que careceria de qualquer sentido. Até mesmo Daniel Pires Novais Dias, crítico à recepção do aludido instituto, entende não haver distinção relevante para justificar sua aplicação exclusiva à responsabilidade contratual:

"A recepção do duty to mitigate the loss foi proposta no Brasil para solucionar situações em que credor mantém-se inerte diante da produção ou agravamento do próprio prejuízo decorrente do inadimplemento do contrato. Trata-se de "solução" apresentada para um problema de responsabilidade civil contratual, ou seja, um problema de imputação de danos que o credor inadimplido poderia ter evitado sofrer ou mesmo minimizado sua extensão quando já inicialmente configurado. Uma recepção que procura dar resposta à seguinte pergunta: a quem e em que medida devem ser imputados os danos decorrentes do

\footnotetext{
${ }^{54}$ PEIXOTO Alessandra Cristina Tufvesson, op.cit. pp. 135-136.
} 
inadimplemento do contrato, mas que o credor poderia ter evitado ou reduzido; ao devedor inadimplente ou ao credor inerte?

No entanto, a abrangência do duty foi ampliada, passando este a ser aplicado (a) no campo da responsabilidade civil aquiliana; e (b) também para os casos de exercício tardio de direito.

A primeira ampliação é justificável, pois o problema jurídico a ela subjacente é o mesmo: a imputação de dano ou seu agravamento evitável pela própria parte lesada. Trata-se de um problema, a imputação de danos, de responsabilidade civil, seja obrigacional ou aquiliana. Neste sentido, não é determinante tratar-se de lesão contratual ou aquiliana, mas sim de tratar-se de evento lesivo imputável a terceiro cujo respectivo potencial danoso pode ser evitado, ou ao menos minimizado, pela própria vítima."

Esta posição, como se verá quando forem analisados os precedentes nacionais em que o instituto foi aplicado, parece ser prevalecente na jurisprudência, que vem aplicando o dever de mitigação indistintamente às hipóteses de responsabilidade civil contratual e extracontratual.

Ressalte-se, ainda, a aplicação do dever da parte de mitigar os próprios danos na esfera processual. O tema, ainda pouco explorado pela doutrina nacional, ganhou atenção com a publicação de artigo de Freddie Didier Jr. na Revista de Processo, do qual colhe-se o seguinte trecho, elucidativo da posição do autor:

"Há uma interessante questão sobre a multa coercitiva (astreinte, prevista no $\S 4 .^{\circ}$ do art. 461 do CPC) que está intimamente relacionada ao princípio da boa-fé processual: a parte, em cujo favor se destina a multa, tem o dever de impedir o aumento desnecessário e irrazoável do seu montante? De que maneira incide sobre a posição jurídica do credor da multa o princípio da boa-fé processual?

O tema é instigante e complexo. Tivemos acesso a dois casos concretos, que podem servir como bons pontos de partida para a solução do problema.

a) A autora de uma demanda, em cujo favor se destinava a multa fixada em uma decisão liminar, fez carga dos autos em novembro de 2002, devolvendo-os ao cartório em janeiro de 2007 - 51 meses depois, portanto. A devolução dos autos judiciais veio acompanhada de petição contendo pedido de execução de multa diária, em valor superior a $\mathrm{R} \$ 13.000 .000,00$ (treze milhões de reais), por suposto descumprimento de ordem judicial que determinava a retirada do nome da autora dos cadastros dos órgãos de proteção ao crédito.

b) Autor de demanda proposta perante os Juizados Especiais, em que pleiteava o retorno do fornecimento de energia elétrica à sua residência e perdas e danos decorrentes da indevida interrupção na prestação do serviço, obteve decisão liminar, com ordem reintegratória, para que o ilícito fosse removido e o serviço voltasse a ser prestado. Houve fixação de multa diária pelo descumprimento. A sentença ratificou a decisão provisória. Houve recurso da empresa-ré. $\mathrm{O}$ autor não noticiou o descumprimento da liminar nem pediu a

\footnotetext{
${ }^{55}$ Op.cit., p. 695.
} 
execução provisória da sentença. Anos depois, após o trânsito em julgado da Turma Recursal que confirmou a sentença, o autor pediu a execução da multa, cujo montantejá se aproximava do primeiro milhão de reais.

Em ambos os casos, como se vê, o montante da multa atingiu valor altíssimo, muito por força do comportamento omissivo do credor-autor.

Para a solução do problema, é preciso investigar primeiro alguns aspectos do direito civil.

O direito privado prevê a existência de um dever do credor de minimizar as suas perdas (duty to mitigate the loss). Esse dever decorre do princípio da boa-fé (art. 422 do CC/2002), sendo um dos deveres anexos que o tratamento cooperativo do vínculo obrigacional impõe ao credor. Ao não diligenciar que o valor dos próprios prejuízos não aumente consideravelmente, o credor cometeria abuso de direito, ferindo, portanto, o princípio da boa-fé. Nesse sentido, foi aprovado o Enunciado 169 da III Jornada de Direito Civil do Conselho da Justiça Federal: 'O princípio da boa-fé objetiva deve levar o credor a evitar o agravamento do próprio prejuízo'. É muito importante perceber que o nosso direito positivo contém norma da qual se permite extrair o dever de mitigar o prejuízo. Esse 'esforço' hermenêutico deve 'valer a pena, pois inúmeras vezes nos deparamos, na prática do foro, com situações em que o credor se mantém inerte face ao descumprimento por parte do devedor, cruzando, literalmente, os braços, vendo crescer o prejuízo, sem procurar evitar ou, ao menos, minimizar sua própria perda'. A previsão de deveres jurídicos para o credor é uma das principais manifestações do princípio da boa-fé. Como ensina Clóvis do Couto e Silva, não caberá ao credor a efetivação da obrigação principal; 'caber-lhe-ão, contudo, certos deveres como os de indicação e de impedir que a sua conduta venha dificultar a prestação do devedor'. ${ }^{, 56}$

Depreende-se da lição do ilustre processualista baiano que o dever de mitigação do credor pode ser aplicado no direito processual como corolário da cláusula geral de boa-fé processual (CPC, art. 14, II), à semelhança do que ocorre no direito civil em relação ao art. 422. No entanto, especificamente em relação à redução das astreintes, existe expressa disposição legal no art. 461, $\$ 6^{\circ}$ do Código de Processo Civil que a autoriza.

\subsection{Precedentes Nacionais}

O STJ, responsável natural para pacificar a matéria, já aplicou o dever de mitigação em algumas oportunidades, as quais serão detalhadamente abordadas devido ao seu elevado grau de importância para a sedimentação do instituto no Brasil. Não se cuidará aqui, dos julgados proferidos por tribunais estaduais, os quais, especialmente no caso do

56 DIDIER JR, Fredie., Multa Coercitiva, Boa-Fé Processual e Supressio: Aplicação do Duty To Mitigate the Loss no Processo Civil. Revista de Processo, vol. 171, ano 34, pp. 46-47. 
Tribunal de Justiça do Rio Grande do Sul, vem aplicando o instituto, repetindo os mesmos equívocos cometidos pelo STJ.

$\mathrm{O}$ primeiro julgado, prolatado antes mesmo da entrada em vigor do Código Civil de 2002, foi o que decidiu o recurso especial $\mathrm{n}^{\mathrm{o}} 32.890 / \mathrm{SP}$, relatado pelo Ministro Ruy Rosado, cujo voto conduziu foi acolhido por unanimidade pela quarta turma. Este acórdão, cuja ementa se transcreve abaixo, é apontado por muitos como sendo o precursor da aplicação do instituto no Brasil:

"FRAUDE À EXECUÇÃO. BOA-FÉ. PROVA DA INSOLVÊNCIA.

1. Nas circunstâncias do negócio, o credor tinha o dever, decorrente da boa-fé objetiva, de adotar medidas oportunas para, protegendo seu crédito, impedir a alienação dos apartamentos a terceiros adquirentes de boa-fé. Limitando-se a incorporadora do empreendimento a propor a ação de execução, sem averba-lá no registro de imóveis ou avisar a financiadora, permitiu que dezena de apartamentos fossem alienados pela construtora a adquirentes que não tinham nenhuma razão para suspeitar da legalidade da compra e venda, inclusive porque dela participou a CEF. Não prevalece, contra estes.

2. Proposta a ação contra devedor solvente (art. 593, II, CPC), a prova da insolvência da devedora e indispensável para caracterizar a fraude a execução. Precedentes da doutrina e da jurisprudência. Recurso conhecido e provido para julgar procedente os embargos de terceiro opostos pelo adquirente."

O recurso teve por origem embargos de terceiro opostos por Gonçalo Ascelino do Nascimento contra ato de penhora realizada no curso de execução movida pela Construtora Oxford contra GDH S.A. Empreendimentos Comerciais e outros. A referida penhora recaiu sobre os imóveis integrantes do Edifício Prado, parte do Projeto Bandeirantes, em São Paulo. Os imóveis aludidos foram alienados pela executada após sua citação para responder à execução, mas antes da realização da penhora.

Em primeira instância, os embargos de terceiro foram julgados procedentes, sob o argumento de que a fraude à execução seria caracterizada somente pela venda posterior à penhora dos bens. A sentença, contudo, foi reformada em segunda instância, sendo o acórdão

\footnotetext{
57 STJ. REsp no 32890/SP. Rel. Ministro Ruy Rosado de Aguiar, Quarta Turma, julgado em 14/11/1994, DJ 12/12/1994.
} 
fundamentado na caracterização de fraude à execução pela alienação posterior à citação do executado.

Em seu recurso especial, os embargantes, alegaram que a compra e venda dos imóveis seria ato jurídico perfeito, que ostentavam a qualidade de terceiros de boa-fé, uma vez que a penhora ainda não havia sido levada à registro e que cabia ao exequente fazer prova de que o executado estaria insolvente para que pudesse ser caracterizada a fraude, e, assim, declarada a ineficácia da compra e venda havida.

O voto do Ministro Ruy Rosado se inicia com a afirmativa de que a jurisprudência da quarta turma, naquele momento, era de que a fraude à execução se configura por uma alienação realizada após a citação do devedor em ação que possa reduzi-lo à insolvência. Com isso, em princípio estaria caracterizada a fraude à execução.

No entanto, dois fundamentos o levaram a excepcionar tal regra no caso concreto. O primeiro é a situação do terceiro de boa-fé

“(...) que acredita na aparência do negócio e muitas vezes investe todos seus recursos na aquisição de um patrimônio que vê desaparecer de suas mãos por força de um processo cuja existência talvez nem tenha condições de saber".

$\mathrm{O}$ argumento que se podia interpretar como uma aplicação do dever de mitigação dos próprios danos pelo credor, e, portanto, o mais relevante para o objeto desta monografia, surge mais adiante no voto do Ministro relator. Afirmou ele que:

“(...) é preciso ter presente que do credor se espera um comportamento processual adequado às circunstâncias, exigindo-se-lhe, por força do princípio da boa fé, que dentre as diversas opções postas pelo sistema à sua disposição, também adote medidas suficientes para impedir que do exercício do seu direito resultem danos desnecessários a terceiros, injustos na medida em que eles não participam da relação originária do débito e não tem por que sofrer danos pelo inadimplemento do outro."

A justificativa da afirmação feita pelo Ministro de que o credor deve adotar "medidas suficientes para impedir que do exercício do seu direito 
resultem danos desnecessários a terceiros", é encontrada nos parágrafos seguintes de seu voto:

"No caso dos autos, há uma especial peculiaridade: a credora e exequente, Construtora Oxford Ltda., interveio no contrato de mútuo firmado entre a CEF e a GDH S/A, na qualidade de construtora dos prédios, sabendo portanto da existência dos imóveis e de sua destinação à venda, bem como desfrutava de condições para acompanhar a execução do contrato entre a CEF e a incorporadora, e dos procedimentos realizados para a comercialização das unidades prontas. (...)

Era de se esperar, portanto, que a empresa credora, na virtualidade do descumprimento das obrigações da sua devedora, tomasse medidas eficazes para a execução do seu crédito e, juntamente com estas, providências que impedissem a provável transferência dos apartamentos a terceiro de boa fé, tais como o arresto de bens, a averbação da existência da ação de execução, a notificação da CEF para não participar operações de financiamento das unidades que existiam para a garantia de sua dívida, etc."

Como se vê, o entendimento que prevaleceu na quarta turma do STJ é de que a construtora não poderia ter permanecido inerte e, somente em sede de contestação aos embargos de terceiro alegar a ineficácia da venda com base em fraude à execução, pois ela sabia que a executada estaria na iminência de vender os apartamentos.

O primeiro ponto a ser discutido é a relação existente entre a Oxford, embargada, e Gonçalo, o embargante. Como o próprio nome da ação manejada sugere, Gonçalo é um terceiro tanto em relação à execução como ao contrato, ambos vinculantes apenas à Oxford e à GDH. É ao menos problemático se enxergar a relação entre a Oxford e Gonçalo tendo aquela por credora e este por devedor, o que seria necessário para que se pudesse falar em um dever de mitigação dos danos por parte da construtora. Não custa rememorar, foi o embargante que ajuizou demanda contra a construtora, com base em constrição indevida de seu patrimônio no curso da execução. A construtora, por sua vez, alegou como matéria de defesa nos embargos de terceiro a ineficácia da compra e venda com base em fraude à execução. Portanto, o dano à Oxford que poderia ser vislumbrado seria apenas a conduta da GDH ao vender o imóvel no curso da execução. A situação da Oxford perante Gonçalo é totalmente diversa. Não sofre ela 
qualquer dano que tenha sido causado por Gonçalo e que ela poderia ter mitigado. Logo se vê, portanto, que não parece fazer sentido a tentativa de enquadrar o julgado do Ministro Ruy Rosado como uma aplicação do instituto do dever de mitigação do próprio prejuízo pelo credor.

Seu argumento quanto à postura do exequente é baseado no conhecimento prévio que a Oxford tinha a respeito da possibilidade de venda dos imóveis por ter figurado como interveniente no contrato de mútuo entre a executada e a Caixa Econômica Federal. Além disso, como construtora do prédio, sabia que a incorporadora venderia os imóveis a terceiros de boa-fé, e, por esse motivo, poderia ter averbado a existência da execução sobre o imóvel, por exemplo.

Tais argumentos não parecem caracterizar uma aplicação do dever de mitigar os próprios danos. Ao invocar a ciência da Oxford, o Ministro parece resolver a questão por uma suposta ausência boa-fé subjetiva da parte, uma vez que parece ser contraditório afirmar que houve fraude à execução quando dela tem ciência o próprio exequente.

Nada disso, entretanto, há de mudar o fato de que o verdadeiro ponto central do acórdão é a defesa dos interesses do terceiro de boa-fé. É essa a correta leitura do julgado acima transcrito. Caso não fossem opostos embargos de terceiro, dificilmente deixaria de ser reconhecida a fraude à execução, como sugere o próprio Ministro relator no início de seu voto, ao relembrar a jurisprudência da quarta turma do STJ no sentido de caracterizar-se a fraude à execução pela alienação posterior à citação do devedor em ação que possa reduzir-lhe à insolvência. Afinal, se por um lado, pode ser alegado que o credor poderia tomar medidas tendentes a evitar a venda do bem pelo devedor, por outro — com muito mais razão —, pode-se afirmar que o devedor jamais poderia vender, no curso de uma execução, o bem dado em garantia do pagamento do próprio montante executado sem, ao menos, cientificar o exequente de tal intenção. É evidente que o Ministro ponderou esta situação, porém, percebendo a grave injustiça que tal solução geraria para o comprador do imóvel, optou por 
relativizar o instituto da fraude à execução para proteger o terceiro de boafé. O que decididamente não há no caso concreto é a aplicação do dever de mitigação dos danos pelo credor.

Novamente por meio de acórdão relatado pelo Ministro Ruy Rosado, o STJ analisou causa em que, embora de forma implícita, discutiu-se o dever do credor de mitigar os próprios danos quando do julgamento do Recurso Especial no 256.274/SP:

"LUCROS CESSANTES. Execução de sentença. Período a considerar. Boa-fé. Seguro. Citação do IRB.

1. Constando da sentença exeqüenda que os lucros cessantes devem ser considerados até a data do efetivo pagamento, essa data limite deve corresponder à do depósito judicial efetuado pela seguradora sobre a parte incontroversa, superior ao valor dos danos emergentes.

2. A avaliação do período a considerar para os lucros cessantes deve ser feita de acordo com a boa-fé objetiva, que impõe ao lesado colaborar lealmente, praticando atos que estavam ao seu alcance, para evitar a continuidade do prejuízo.

3.Depositado o valor suficiente para a reconstrução do prédio onde se localizava a cozinha do restaurante explorado pelo segurado, é de se ter que nessa data terminou a contagem dos lucros cessantes, ampliado o período de mais 90 dias, julgado pela sentença como necessário para as obras.

4. A citação do IRB deveria ter sido requerida na contestação da seguradora, sendo intempestivo o requerimento feito já no processo de execução da sentença.

5. Omissões inexistentes.

Recurso conhecido em parte e provido." 58

Em resumo, houve um incêndio no estabelecimento do Novo Hotel Cacique, parte recorrida, sendo tal fato coberto por seguro contratado junto à seguradora Sul América. Nas instâncias inferiores, condenou-se a seguradora no pagamento de indenização por lucros cessantes que cobririam dois períodos distintos. O primeiro período teria por termo inicial o $30^{\circ}$ dia após a ocorrência do sinistro, findando-se na data na qual foi rejeitado um cheque enviado pela seguradora. Registre-se que após essa recusa, a seguradora depositou o valor incontroverso, em montante suficiente para a reconstrução das instalações comprometidas pelo incêndio. Já o segundo período corresponderia ao tempo entre a data da propositura

\footnotetext{
${ }^{58}$ STJ. REsp no 256.274/SP. Rel. Ministro Ruy Rosado de Aguiar, Quarta Turma, julgado em 26/09/2000, DJ 18/12/2000.
} 
da ação indenizatória e a data em que efetivamente viesse a ser pago o valor da indenização.

O entendimento que prevaleceu, como se vê da ementa, é de que a recorrida poderia, sem qualquer esforço incomum, valer-se do montante depositado para recuperar seu prejuízo, e, com isso, impedir o agravamento dos lucros cessantes que seriam devidos. Diante da inércia da parte, o STJ reduziu o valor dos lucros cessantes, retirando de seu cálculo o montante correspondente ao período posterior ao $90^{\circ}$ dia após o depósito, tempo este considerado suficiente para que as obras fossem devidamente concluídas.

Neste caso, há uma evidente postura de omissão da parte prejudicada em relação ao agravamento de seus danos. Diversamente do que ocorreu em relação ao outro julgado relatado pelo Ministro Ruy Rosado, aqui o principal fundamento do julgado foi a aplicação da boa-fé como fonte do dever da parte credor de evitar o agravamento do próprio prejuízo. Muito embora não tenha expressamente aludido ao dever do credor de mitigar os próprios danos, parece evidente, pela conclusão alcançada, que o julgado foi influenciado pela referida regra. Note-se, ainda, que foi devidamente registrado que a conduta do credor seria restrita aos "atos que estavam ao seu alcance", o que em muito se assemelha ao supracitado conceito de razoabilidade.

Mais recentemente, em 2010, o STJ invocou expressamente o dever de mitigação em acórdão relatado pelo Desembargador convocado do Tribunal de Justiça do Estado do Rio Grande do Sul, Vasco Della Giustina:

"DIREITO CIVIL. CONTRATOS. BOA-FÉ OBJETIVA. STANDARD ÉTICOJURÍDICO. OBSERVÂNCIA PELAS PARTES CONTRATANTES. DEVERES ANEXOS. DUTY TO MITIGATE THE LOSS. DEVER DE MITIGAR O PRÓPRIO PREJUÍZO. INÉRCIA DO CREDOR. AGRAVAMENTO DO DANO. INADIMPLEMENTO CONTRATUAL. RECURSO IMPROVIDO.

1. Boa-fé objetiva. Standard ético-jurídico. Observância pelos contratantes em todas as fases. Condutas pautadas pela probidade, cooperação e lealdade.

2. Relações obrigacionais. Atuação das partes. Preservação dos direitos dos contratantes na consecução dos fins. Impossibilidade de violação aos preceitos éticos insertos no ordenamento jurídico.

3. Preceito decorrente da boa-fé objetiva. Duty to mitigate the loss: o dever de mitigar o próprio prejuízo. Os contratantes devem tomar as medidas necessárias e possíveis para que o dano não seja agravado. A parte a que a perda aproveita não 
pode permanecer deliberadamente inerte diante do dano. Agravamento do prejuízo, em razão da inércia do credor. Infringência aos deveres de cooperação e lealdade.

4. Lição da doutrinadora Véra Maria Jacob de Fradera. Descuido com o dever de mitigar o prejuízo sofrido. $\mathrm{O}$ fato de ter deixado o devedor na posse do imóvel por quase 7 (sete) anos, sem que este cumprisse com o seu dever contratual (pagamento das prestações relativas ao contrato de compra e venda), evidencia a ausência de zelo com o patrimônio do credor, com o consequente agravamento significativo das perdas, uma vez que a realização mais célere dos atos de defesa possessória diminuiriam a extensão do dano.

5. Violação ao princípio da boa-fé objetiva. Caracterização de inadimplemento contratual a justificar a penalidade imposta pela Corte originária, (exclusão de um ano de ressarcimento).

6. Recurso improvido."

Neste caso, houve uma venda de imóvel mediante preço a ser pago em parcelas, tendo o comprador, embora imitido na posse do imóvel em 1994, inadimplido o pagamento do preço contratual desde o início, vindo a abandonar o imóvel em 2001 (na sentença afirmou-se que o abandono dataria de 1999, mas tal conclusão foi modificada em segunda instância). A ação foi ajuizada em 16 de outubro de 2001, pleiteando a reintegração na posse do imóvel e indenização pelo tempo em que a autora ficou sem poder fruir de seu imóvel.

Ao julgar a demanda, o STJ, confirmando o acórdão da apelação, entendeu que, conquanto tenha a ação sido ajuizada tempestivamente no que se refere ao prazo prescricional — à época de 20 anos —, não poderia a autora obter indenização correspondente a todo o período em que o réu ocupou o imóvel. Com efeito, reconheceu-se que a autora deveria tomar as providências razoáveis para impedir o agravamento de seus danos. Pelo contrário, permaneceu ela, durante quase 10 anos, absolutamente inerte, não tomando qualquer providência para recuperar seu imóvel, exceto por algumas notificações, as quais, entretanto, não foram seguidas de qualquer medida eficaz. Veja-se, nesse sentido, o seguinte trecho do voto condutor do acórdão:

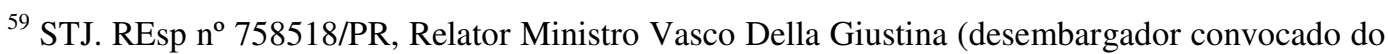
TJ/RS), Terceira Turma, julgado em 17/06/2010, DJe 28/06/2010.
} 
"Destarte, a boa-fé objetiva é fonte de obrigação que permeia a conduta das partes a influir na maneira em que exercitam os seus direitos, bem como no modo em que se relacionam entre si. Neste rumo, a relação obrigacional deve ser desenvolvida com o escopo de se preservarem os direitos dos contratantes na consecução dos fins avençados, sem que a atuação das partes infrinja os preceitos éticos insertos no ordenamento jurídico.

Com esse entendimento, avulta-se o dever de mitigar o próprio prejuízo, ou, no direito alienígena, duty to mitigate the loss: as partes contratantes da obrigação devem tomar as medidas necessárias e possíveis para que o dano não seja agravado. Desse modo, a parte a que a perda aproveita não pode permanecer deliberadamente inerte diante do dano, pois a sua inércia imporá gravame desnecessário e evitável ao patrimônio da outra, circunstância que infringe os deveres de cooperação e lealdade."

Todavia, não perdeu a autora todo o direito à indenização por lucros cessantes. Foi reconhecido que teria ela o direito às parcelas de fruição referentes ao período entre o ajuizamento da demanda e a data do efetivo cumprimento do mandado de reintegração de posse, o que ocorreu no dia 10 de fevereiro de 2003.

Ao contrário do que se verificou no primeiro acórdão relatado pelo Ministro Ruy Rosado, trata-se aqui de hipótese em que pode ser aplicado o dever de mitigação dos próprios danos. Em primeiro lugar, foi o credor que sofreu danos e ele quem deveria tê-los mitigados. Embora se trate de constatação óbvia, infelizmente este requisito absolutamente básico do instituto vem sendo ignorado pela jurisprudência brasileira, o que apenas fortalece as críticas à sua recepção ${ }^{60}$.

A causa do dano, por sua vez, foi provocada exclusivamente pela conduta do réu, ao inadimplir o contrato. Por mais que se possa criticar a inércia da parte credora, não houve, de sua parte, qualquer concorrência de culpa para a produção do evento danoso (inadimplemento do preço do contrato), não se tratando, assim, de culpa concorrente, mas sim de uma inércia em relação ao agravamento do dano.

Além disso, perquiriu-se a razoabilidade de se exigir do credor a mitigação de seu prejuízo, cogitando-se, por exemplo, se houve algum justo impedimento. Ressalte-se que não houve aqui equívoco em relação à

60 TJRS. Apelação Cível no 70028138113, Décima Segunda Câmara Cível, Relator Des. Umberto Guaspari Sudbrack, Julgado em 29/01/2009. 
distribuição do ônus da prova: compete ao réu provar que o credor poderia ter tomado medidas razoáveis para evitar o agravamento de seu dano, o que no caso é evidente, pois o credor teve anos para manejar a ação possessória. No entanto, compete ao credor, uma vez feita tal alegação, provar que houve justo impedimento para que ele pudesse mitigar o dano, ônus este do qual não conseguiu se desincumbir a autora. Tudo que a construtora alegou foi que não houve, de sua parte violação à boa-fé, pois ajuizou a ação dentro do prazo prescricional, argumento este que não poderia mesmo prosperar.

Correta também foi a delimitação do período passível de ser indenizado. Como a autora poderia ter ajuizada a demanda possessória imediatamente quando do inadimplemento cometido pelo réu, e isto somente foi feito em 16 de outubro de 2002, considerou-se apenas o período posterior à propositura da ação, cessando a sua contagem na data em que a autora readquiriu a posse do imóvel por meio de decisão liminar.

Faça-se a ressalva, entretanto, que a situação da limitação do direito pelo seu não exercício ao longo do tempo também poderia ter sido resolvida pela aplicação da supressio. Esta figura permite a tutela da confiança legítima de uma parte quando esta decorre do não exercício do direito pela outra. No entanto, optou o STJ por resolver a questão à luz do dever de mitigar os danos, sem enfrentar qualquer discussão acerca da supressio.

Há quatro acórdãos pelo STJ, todos relatados pela Ministra Maria Thereza de Assis Moura, os quais, surpreendentemente, aplicaram o referido instituto em matéria penal ${ }^{61}$. Para facilitar a compreensão das críticas a seguir formuladas, transcreve-se um dos aludidos acórdãos, no qual ficam evidentes as imprecisões cometidas pela Ministra:

\footnotetext{
${ }^{61}$ STJ. HC 266.426/SC, Relatora Ministra Maria Thereza de Assis Moura, Sexta Turma, julgado em 07/05/2013, DJe 14/05/2013; STJ. HC 171.753/GO, Relatora Ministra Maria Thereza de Assis Moura, Sexta Turma, julgado em 04/04/2013, DJe 16/04/2013; STJ. HC 137.549/RJ, Relatora Ministra Maria Thereza de Assis Moura, Sexta Turma, julgado em 07/02/2013, DJe 20/02/2013; STJ. HC 131.830/SP, Rel. Ministra Maria Thereza de Assis Moura, Sexta Turma, julgado em 18/12/2012, DJe 01/02/2013.
} 
"PENAL. HABEAS CORPUS. FALSIDADE IDEOLÓGICA. PRÉVIO MANDAMUS DENEGADO. PRESENTE WRIT SUBSTITUTIVO DE RECURSO ORDINÁRIO. INVIABILIDADE. VIA INADEQUADA. REGISTRO CIVIL EM DUPLICIDADE. NASCIMENTO ALEGADO EM DOIS PAÍSES DIVERSOS. BUSCA DA DUPLA CIDADANIA. EXTINÇÃO DA PUNIBILIDADE. PRESCRIÇÃO. INOCORRÊNCIA. TRANCAMENTO DA AÇÃO PENAL. CONHECIMENTO POSTERIOR DA INDEVIDA CONDUTA. CONSEQUENTE INGRESSO DE AÇÃO ANULATÓRIA PELOS ACUSADOS. BOA-FÉ. DUTY TO MITIGATE THE LOSS. AÇÃO PENAL. AFETAÇÃO AO BEM JURÍDICO TUTELADO. NÃO INCIDÊNCIA. PRINCÍPIO DA OFENSIVIDADE. ATIPICIDADE DA CONDUTA. OCORRÊNCIA. FLAGRANTE ILEGALIDADE. EXISTÊNCIA. HABEAS CORPUS NÃO CONHECIDO. ORDEM CONCEDIDA DE OFÍCIO.

1. É imperiosa a necessidade de racionalização do emprego do habeas corpus, em prestígio ao âmbito de cognição da garantia constitucional e em louvor à lógica do sistema recursal. In casu, foi impetrada indevidamente a ordem como substitutiva de recurso ordinário.

2. Os pacientes registraram em duplicidade o nascimento do filho, em países diversos, crendo que com a conduta regularizariam a dupla cidadania do seu rebento, sendo que, ao serem posteriormente informados do caráter indevido do ato, ingressaram com uma ação anulatória de registro civil para regularizar a situação, o que trouxe ao conhecimento do órgão ministerial a quaestio e motivou a exordial acusatória.

3. Não há falar em extinção da punibilidade pelo reconhecimento da prescrição, eis que inexistiu decurso temporal superior ao previsto em lei, pois o termo inicial para a contagem do prazo é o dia em que o fato se tornou conhecido, nos termos do artigo 111, inciso IV, do Código Penal.

4. De se invocar, no caso, o cânone da boa-fé objetiva, que ecoa por todo o ordenamento jurídico, não se esgotando no campo do Direito Privado, no qual, originariamente, deita raízes; destacando-se, dentre os seus subprincípios, o duty to mitigate the loss.

5. Na espécie, existe manifesta ilegalidade, visto que somente se trouxe a lume o imbróglio após o ingresso da ação anulatória pelos pacientes para regularizar a situação, em franca atitude de mitigar, dentro do empenho possível e razoável, o evento danoso - duty to mitigate the loss.

6. Acura-se dos autos a ausência da afetação do bem jurídico tutelado, fé pública, ensejando, portanto, a atipicidade da conduta dos pacientes, em atenção ao princípio da ofensividade.

7. Habeas corpus não conhecido. Ordem concedida, de ofício, a fim de, reconhecendo a atipicidade da conduta, trancar a ação penal.."62

Basicamente, tratou o caso da seguinte situação: os pais de uma criança nascida em território estrangeiro (Paraguai), sem saber como proceder para que lhe fosse conferida dupla cidadania, promoveram, no Brasil, um segundo registro de nascimento. Evidentemente, tal registro é falso, materializando, assim, o crime de falsidade ideológica, prevista no art. 299 do Código Penal. Antes que fosse tomada qualquer providência por

\footnotetext{
${ }^{62}$ STJ. HC 266.426/SC, Rel. Ministra Maria Thereza de Assis Moura, Sexta Turma, julgado em 07/05/2013, DJe 14/05/2013.
} 
parte das autoridades policiais ou do Ministério Público, os pais ajuizaram ação anulatória tendo por objeto o segundo registro.

Ao analisar o habeas corpus, entendeu a Ministra relatora que ao ajuizar a ação anulatória teriam os pais agido em consonância com a boa-fé objetiva, mitigando seus danos, e, por isso, não deveriam ser punidos pela conduta. Tal voto, seguramente, muito mais por seu resultado prático do que em prestígio à inusitada aplicação do dever de mitigação, foi seguido pela unanimidade dos Ministros votantes. No entanto, o acórdão acima transcrito é merecedor de diversas críticas.

Registre-se, primeiramente, que não há porque censurar a Ministrar simplesmente por ter aplicado um instituto naturalmente associado à responsabilidade civil contratual em matéria penal. Afinal, como já dito, o princípio da boa-fé objetivo não possui sua aplicabilidade limitada à matérias contratuais ou mesmo ao direito civil, podendo ser aplicada a outros ramos do direito, desde que respeitadas as disposições específicas deste último. Muito embora este trabalho não pretenda avançar no campo do direito penal, basta imaginar, por exemplo, uma hipótese em que uma pessoa invade o computador de outra e posta fotos pessoais do proprietário do computador em sua rede social, de forma a materializar-se o crime de difamação. O proprietário do computador, uma vez tendo recuperado seu equipamento, não toma qualquer providência em relação às fotos e, com isso, potencializa o dano sofrido. Sem prejuízo das considerações sobre interrupção do nexo causal em matéria de direito penal, não configuraria qualquer absurdo caso o julgador, complementasse sua decisão com uma referência ao instituto do dever do credor de mitigar os danos.

Há um aspecto fundamental no exemplo mencionado: o crime de difamação comporta ação penal privada, isto é, o processo decorrente de sua prática é iniciado por iniciativa do próprio titular do bem ofendido (a honra). É ele, portanto, o credor, por assim dizer, que deixou de mitigar os prejuízos sofridos, pois podia impedir o agravamento de seu dano e nada fez. 
Diversamente, no acórdão relatado pela Ministra Maria Thereza de Assis Moura há um equívoco, o qual, por si só, torna completamente inservível o precedente como um exemplo de aplicação do instituto: a suposta mitigação foi feita pelo devedor, isto é, pelo próprio causador do dano, réu da ação penal. Não se está diante de hipótese de incidência do instituto quando é o próprio devedor que tenta mitigar os efeitos de seu descumprimento. Não se trata de um equívoco exclusivamente cometido pela Ministra. Outro julgado que afirma estar aplicando o dever de mitigação comete o mesmo erro. Neste caso, oriundo do Tribunal de Justiça do Rio Grande do Sul, aplicou-se o instituto em hipótese na qual a companhia aérea, após cancelar o vôo de determinados passageiros, ofereceu a eles acomodações para que passassem a noite. A indenização foi reduzida, com o que não se discorda, porém a fundamentação aponta para a aplicação do dever de mitigação de danos, o que é até mesmo paradoxal. Veja-se, a título exemplificativo, a ementa do julgado:

\begin{abstract}
“APELAÇÃO CÍVEL. TRANSPORTE AÉREO. REPARAÇÃO POR DANOS MORAIS. ATRASO DE VÔO. REVÉS MORAL DIAGNOSTICADO. MITIGAÇÃO DO PREJUÍZO POR PARTE DA COMPANHIA AÉREA. REDUÇÃO DO VALOR NOMINAL DA INDENIZAÇÃO.

Para a caracterização do dever de indenizar, não basta a existência de conduta, nexo de causalidade e dano; é necessário, ainda, que a conduta praticada ultrapasse os lindes jurídicos, para ressoar seus efeitos no terreno da antijuridicidade. Com efeito, a documentação acostada aos autos comprova o revés moral experimentado pela tripulante, porquanto esta enfrentou situação constrangedora e embaraçosa com o cancelamento de seu vôo e alteração posterior de rotas tudo por força da precariedade no serviço prestado pela ré. Indenização por revés moral no valor nominal de $\mathrm{R} \$ 1.500,00$, montante inferior a julgados pretorianos similares, por conta da conduta previdente da parte ré em mitigar o seu próprio prejuízo oferecimento de passeios e refeições à tripulante após o evento danoso. Apelo provido." ${ }^{63}$
\end{abstract}

Existem diversas peculiaridades para a atuação do devedor no sentido de minimizar os efeitos de seu inadimplemento (direito de cura, nachfrist, uma simples redução da indenização, e tantos outros exemplos), as quais, certamente, não são objeto deste estudo. O que não se pode fazer é

\footnotetext{
${ }^{63}$ TJRS. Apelação Cível no 70028138113 , Décima Segunda Câmara Cível, Relator Des. Umberto Guaspari Sudbrack, Julgado em 29/01/2009.
} 
desvirtuar o instituto do dever de mitigação dos próprios danos pelo credor, fazendo com que passe a abarcar situações nas quais o credor não se omitiu em relação ao dano, que pode ser efetivamente evitado pelo próprio devedor. Infelizmente, julgados que, como estes, aplicam açodadamente o referido instituto sem se ater à melhor técnica, vem se alastrando pelos tribunais do sul do país. Para o sucesso do referido instituto, há de se proceder com a devida serenidade em sua aplicação, pois o dever de mitigação não é uma solução universal, mas sim uma regra específica que possui pressupostos próprios a serem respeitados.

Para que se conclua a análise do caso julgado sob a relatoria da Ministra Maria Thereza de Assis Moura, deve ser registrado que a conclusão que se teria obtido sem a incorreta aplicação do dever de mitigação dos próprios prejuízos aparentemente seria a mesma, devido à constatação, no acórdão, da "ausência da afetação do bem jurídico tutelado, fé pública, ensejando, portanto, a atipicidade da conduta dos pacientes, em atenção ao princípio da ofensividade". Ou seja, é de se destacar que, antes de utilizar equivocadamente o dever de mitigação como argumento subsidiário, a Ministra já havia adequadamente resolvido a questão à luz do direito penal.

Há, ainda, um interessante julgado aplicando o dever de mitigar as próprias perdas em matéria consumerista, relatado pela Ministra Nancy Andrighi:

"DIREITO DO CONSUMIDOR. RECURSO ESPECIAL. AÇÃO CIVIL PÚBLICA. CLÁUSULA QUE PREVÊ RESPONSABILIDADE DO CONSUMIDOR QUANTO AOS HONORÁRIOS ADVOCATÍCIOS CONTRATUAIS DECORRENTES DE INADIMPLEMENTO CONTRATUAL. RECIPROCIDADE. LIMITES. ABUSIVIDADE. NÃO OCORRÊNCIA.

1. Os honorários contratuais decorrentes de contratação de serviços advocatícios extrajudiciais são passíveis de ressarcimento, nos termos do art. 395 do CC/02.

2. Em contratos de consumo, além da existência de cláusula expressa para a responsabilização do consumidor, deve haver reciprocidade, garantindo-se igual direito ao consumidor na hipótese de inadimplemento do fornecedor.

3. A liberdade contratual integrada pela boa-fé objetiva acrescenta ao contrato deveres anexos, entre os quais, o ônus do credor de minorar seu prejuízo buscando soluções amigáveis antes da contratação de serviço especializado.

4. O exercício regular do direito de ressarcimento aos honorários advocatícios, portanto, depende da demonstração de sua imprescindibilidade para solução 
extrajudicial de impasse entre as partes contratantes ou para adoção de medidas preparatórias ao processo judicial, bem como da prestação efetiva de serviços privativos de advogado e da razoabilidade do valor dos honorários convencionados.

5. Recurso especial provido."

Neste caso, discutiu-se uma cláusula contratual que impunha ao consumidor inadimplente a obrigação de arcar com os custos da contratação, pela empresa, de advogados para fins extrajudiciais. O resultado final do julgamento, como se pode ver de sua ementa, é que somente seriam considerados devidos os honorários caso fosse conferido igual direito ao consumidor e a contratação se demonstrasse realmente necessária e proporcional. Ao fundamentar este último ponto, o da proporcionalidade, a Ministra relatora tratou do dever de mitigação de danos:

"Outrossim, vale trazer à baila o dever geral imposto aos credores, em virtude da aplicação direta da boa-fé objetiva, de minorar as próprias perdas (duty to mitigate the loss). Assim, se impõe ao credor o ônus de adotar medidas menos prejudiciais a ambas as partes contratantes, em obediência ao dever anexo de cooperação e lealdade. Nessa ordem de ideias, antes que se proceda à efetiva contratação de advogado para a cobrança de débitos inadimplidos entre partes contratantes, é de se exigir a demonstração de tentativas de solução amigável frustradas. Do contrário, se a partir da mora o credor já contrata advogado, impingindo ao devedor um acréscimo considerável, muitas vezes, bastante superior aos encargos de mora, a contratação será desproporcional, portanto, abusiva e não sujeita ao ressarcimento."

Mais uma vez, o dever de mitigar é utilizado como um argumento subsidiário, dando a entender que se trata de uma regra geral da responsabilidade civil, o que confirma a sua adoção como um dever ligado à boa fé objetiva que todos os contratantes, independente do tipo de relação material em discussão, devem guardar antes e durante toda a execução do contrato. Aqui, no entanto, ao contrário dos julgados relatados pela Ministra Maria Thereza Assis de Moura, o instituto é aplicado sem que sejam feridas suas principais características. De fato, ao cobrar os honorários de seu

\footnotetext{
${ }^{64}$ STJ. REsp n ${ }^{\circ}$ 1274629/AP, Relatora Ministra Nancy Andrighi, Terceira Turma, julgado em 16/05/2013, DJe 20/06/2013.
} 
advogado do consumidor que deu causa a um inadimplemento contratual seu, é inegável que o fornecedor seria o credor da responsabilidade pelo eventual dano praticado.

A solução, igualmente, é de que o ressarcimento dos honorários de advogado não seria devido se fosse abusiva também é consonante com os já delineados contornos do dever de mitigar os danos. Neste particular, ressalte-se que é a busca por uma solução amigável - a qual poderia evitar totalmente a necessidade de contratação de advogado - que é tida como a medida razoável que poderia ser tomada pelo credor. Apesar de ser necessário analisar os fatos do caso concreto para que se determine se seria razoável exigir do credor que buscasse minorar seus danos, pois caso a solução amigável restasse absolutamente inviabilizada por alguma característica do caso concreto, é evidente que esta circunstância repercutiria na aplicação do dever de mitigar. Se, por um lado, não se está diante de uma causa em que o credor litigava diretamente com o devedor, ao menos foram respeitadas as principais características do dever de mitigação quando ele foi abordado no acórdão para justificar a revisão de uma cláusula abusiva.

Conclui-se, portanto, pelos termos dos julgados do Superior Tribunal de Justiça sobre o tema, que o dever de mitigar os próprios danos vem sendo aplicado no Brasil como um corolário da boa-fé objetiva e a consequência que se tem admitido para o seu descumprimento é a mesma aplicada pelo mundo: a perda do direito de cobrar a indenização de forma integral. Deve ser fazer a ressalva, ainda, que, especialmente ao aplica-lo em matéria de direito penal, não se valeu o Superior Tribunal de Justiça da melhor técnica, pois falhou em perceber que se tratava de uma tentativa do próprio réu (analogamente, o devedor) em minorar as consequências de seu ato ilícito. Ou seja, além de já existirem soluções no próprio direito penal para tal fato (aplicação do princípio da ofensividade, arrependimento eficaz, etc.), o dever de mitigar não poderia ser aplicado nem mesmo por analogia. 
A recepção do instituto, portanto, tem se dado, em alguns casos, em prejuízo de seus requisitos e características, o que, por sua vez, faz com que ele acabe tomando o espaço de outros institutos que poderiam resolver os casos concretos. O que vem sendo aplicado no Brasil é muito mais uma concepção vaga ligada à noção geral de existência do dever de mitigar os danos do que a regra internacionalmente consagrada de que o credor deve mitigar seus próprios danos sob pena de não pode cobra-lo integralmente do devedor.

É preciso destacar que apenas no segundo acórdão relatado pelo Ministro Ruy Rosado o dever de mitigar foi associado à possibilidade de realização de uma transação substituta, as quais são a principal hipótese de incidência deste dever no cenário internacional. Este sim é o âmbito específico de aplicação do dever de mitigar, como será demonstrado no próximo capítulo. 


\section{CAPÍTULO III - O DEVER DE MITIGAÇÃO DE DANOS NA CISG}

3.1 A CISG: Contexto Histórico e Princípios 3.2 Os Esforços Conciliatórios na Convenção 3.3 A Boa-Fé na CISG 3.4 Aplicação do Dever de Mitigação com Base na CISG

\subsection{A CISG: Contexto Histórico e Princípios}

Os esforços para a construção de uma convenção regulando as compras e vendas internacionais de mercadorias se iniciaram em 1930, no Instituto Internacional para a Unificação do Direito Privado - UNIDROIT. A segunda guerra mundial e a turbulência que a sucedeu, contudo, acabaram por interromper, durante várias décadas, os avanços empreendidos no sentido de se elaborar um único diploma legal que fosse capaz de regular o comércio internacional ${ }^{65}$.

Foi somente em 1972 que duas convenções simultaneamente elaboradas - a Lei Uniforme Sobre a Venda Internacional de Bens e a Lei Uniforme Sobre a Formação de Contratos Internacionais de Venda de Bens — , baseadas em uma conferência diplomática realizada em Haia em 1964, passaram a vigorar entre a Bélgica, Alemanha Ocidental, Gambia, Reino Unido, Israel, Itália Luxemburgo, Holanda e San Marino ${ }^{66}$.

Entretanto, as aludidas convenções foram criticadas por apresentarem conceitos tradicionalmente ocidentais, e, por essa razão, não foram adotadas por muitos países fora da Europa $^{67}$. O restrito número de países que adotou tal convenção levou a UNCITRAL - Comissão das Nações Unidas sobre o Direito do Comércio Internacional —, formada em 1968, a instalar, em sua segunda sessão, realizada em 1969, uma subcomissão específica para buscar conceitos efetivamente internacionais

65 Nota explicativa da Secretaria da Comissão das Nações Unidas sobre o Direito do Comércio Internacional. Disponível em <http://cisgw3.law.pace.edu/cisg/text/secomm/secomm-77.html.> Acesso em 02/04/13.

66 MASKOW, Dietrich; ENDERLEIN, Fritz. INTERNATIONAL SALES LAW. Disponível em $<$ http://cisgw3.law.pace.edu/cisg/biblio/enderlein-art77.html.> Acesso em 02/04/13.

${ }^{67}$ Nota explicativa da Secretaria da Comissão das Nações Unidas sobre o Direito do Comércio Internacional. Disponível em <http://cisgw3.law.pace.edu/cisg/text/secomm/secomm-77.html.> Acesso em 02/04/13. 
para a elaboração do texto de uma nova convenção. $\mathrm{O}$ grupo de trabalhos chegou até mesmo a formular consultas diretas aos países que deixaram de ratificar as Leis Uniformes para que fossem levadas em conta as principais críticas ao texto proposto ${ }^{68}$.

Em 1977, na décima sessão da UNCITRAL, foi apresentado pelo grupo de trabalhos designado para este fim a minuta final da Convenção sobre a Compra e Venda Internacional de Mercadorias. Na sessão seguinte da UNCITRAL, realizada em 1978, foi apresentada uma minuta final do que pretensamente seria uma Convenção sobre a Formação dos Contratos de Compra e Venda Internacional de Mercadorias. No entanto, ambas as convenções foram integradas num único documento, mantendo-se o nome atribuído à primeira minuta ${ }^{69}$.

A minuta consolidada foi objeto de debate em uma conferência diplomática realizada em Viena entre os dias 10 de março e 11 de abril de 1980 por representantes de 62 países e 8 organizações internacionais. Após mais de 300 propostas de emendas ao texto final, a maior parte delas rejeitada pelas delegações presentes, o texto final foi aprovado no dia $11 \mathrm{de}$ abril de 1980, com algumas abstenções, porém sem qualquer voto contrário.

A preocupação com o caráter internacional da convenção, refletida na forma de trabalho da subcomissão, tornou viável a sua assinatura, logo em seus primeiros anos de existência, por diversos países que rejeitaram as convenções anteriores. Entre os signatários originais da convenção estavam presentes países de diferentes regiões e nível de desenvolvimento econômico: Argentina, China, Egito, França, Hungria, Itália, Lesoto, Síria, Estados Unidos, Iugoslávia e Zâmbia. Nos anos que seguiram, verificou-se um crescente interesse internacional pela convenção, o que se refletiu com sua adoção por países como a Bielorrúsia (1989), Tchecoslováquia (1981), Ghana (1981), Iraque (1990), e, até mesmo, a União Soviética (1990).

\footnotetext{
${ }^{68}$ MASKOW, Dietrich; ENDERLEIN, Fritz. Op.cit.

${ }^{69}$ Idem.
} 
Atualmente, a convenção conta com 79 estados signatários, sendo que o último a ter se vinculado a seu texto é o Brasil, o qual depositou o instrumento de adesão no dia 4 de março de $2013^{70}$. A convenção entrará em vigor no Brasil no dia $1^{\circ}$ de abril de $2014^{71}$.

\subsection{Os Esforços Conciliatórios na Convenção}

Desde sua concepção, o principal objetivo dos responsáveis pela redação dos artigos da Convenção de Viena era produzir normas que não apenas refletissem as melhores práticas de comércio internacional, mas, especialmente, que fossem universalmente aceitas, evitando, assim, repetir o desinteresse de países não-europeus em relação à convenção, como ocorreu com as convenções de $1972^{72}$.

O prof. John O. Honnold, ex-secretário da UNCITRAL e chefe da divisão de comércio internacional das Nações Unidas entre 1969 e 1974, aponta alguns dos mecanismos que possibilitam a superação das diferenças entre os diferentes países signatários da convenção:

"The effort, in drafting the Convention, to avoid legal idioms that have divergent local meanings and, instead, to speak in terms of physical events that occur in international trade; the use of the legislative history of the Convention as a means of escape from preconceptions derived from domestic laws; and the dissemination and use of international case law (jurisprudence) and scholarly critique (doctrine). ${ }^{, 73}$

De fato, todo o texto a convenção foi pensado a partir da vontade de se produzir uma legislação uniforme e independente dos ordenamentos

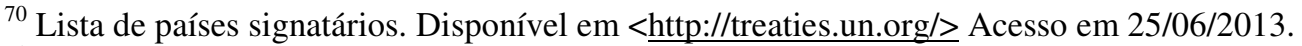

${ }^{71}$ Notícia publicada no site da Organização das Nações Unidas. Disponível em $<$ http://www.onu.org.br/brasil-adere-a-convencao-da-onu-sobre-contratos-internacionais-decompra-e-venda-de-mercadorias/ acessado em 25/06/2013 às 11:21> Acesso em 02/06/13. 72 HONNOLD, John O. Uniform Law for International Sales under the 1980 United Nations Convention. Disponível em <http://www.cisg.law.pace.edu/cisg/biblio/honnold.html $>$ Acesso em 02/07/13.

${ }^{73}$ Idem.
} 
jurídicos estatais $^{74}$, para reduzir as incertezas inerentes ao comércio entre países por vezes completamente distintos em sua cultura e ordenamento jurídico.

Um dos primeiros desafios foi definir o campo de aplicação da convenção. Neste ponto, optou-se por excluir de seu campo de incidência questões sensíveis e que poderiam levar a divergências inconciliáveis entre os signatários $^{75}$. Como reflexo desta busca por produzir um texto que não acabasse por restringir a aceitação da convenção, os seus primeiros artigos do texto final apresentam, além da definição das matérias sujeitas à convenção, diversas exceções à sua aplicação e assunto que, por disposição expressa, não serão por ela regulados.

Entre os pontos não regulados pela convenção, podemos destacar validade do contrato (art. $4^{\circ}$, "a") e os efeitos do contrato em relação à propriedade dos bens (art. $4^{\circ}$, “b"). Sobre este tema, entendeu-se mais prudente mantê-los sob a tutela das leis nacionais aplicáveis como resultado da aplicação das regras de direito internacional privado, evitando, assim, uma difícil negociação que atrasaria os trabalhos dos redatores e, possivelmente, diminuiria o número total de países signatários.

Além disso, certas modalidades específicas de contratos de compra e venda internacional foram expressamente excluídos do âmbito de aplicação da convenção: bens de uso pessoal (art. $2^{\circ}$, “a”), bens adquiridos por meio de leilão (art. 2o, "b”), bens adquiridos por força de comando judicial ou legal (art. 20 "c"), compra e venda de valores mobiliários (art. 2 $2^{\circ}$, “d"), compra e venda de navios e aeronaves (art. $2^{\circ}$, "e"), e contratos de compra e venda de energia elétrica (art. $2^{\circ}$, “f”). Finalmente, para tornar sua aceitação ainda mais irrestrita, inclui-se a possibilidade de derrogação, total ou parcial, da convenção (art. $\left.6^{\circ}\right)$.

\footnotetext{
74 SHEEHY, Benedict. Good Faith in the CISG: Interpretation Problems in Article 7. Disponível em $<$ http://law.bepress.com/cgi/viewcontent.cgi?article=1815\&context=expresso $>$ Acesso em 03/07/13.

75 KRÖLL, Stefan. Selected Problems Concerning the CISG's Scope of Application. Disponível em <http://www.cisg.law.pace.edu/cisg/biblio/kroll.html > Acesso em 04/07/13.
} 
Outra questão extremamente sensível com a qual tiveram de lidar os redatores da convenção foi a inclusão de juros entre os montantes devidos a título indenizatório. Como a Sharia - conjunto de regras consideradas sagradas para os povos que professam a fé islâmica - proíbe a cobrança de juros (riba), a menção à aplicação de juros sobre o montante devido acabou sendo breve, sem qualquer tipo de referência sobre sua forma de cálculo (art. 78), para não desencorajar os países muçulmanos a aderirem à convenção ${ }^{76}$.

De um modo geral, podemos concluir que os redatores do texto da convenção lograram êxito em sua missão de construir um diploma normativo que não fosse demasiadamente apegado a uma única forma de visão jurídica, o que se atesta pelo número de países signatários, os quais incluem nações de todas as regiões do mundo.

\subsection{A Boa-Fé na CISG}

Duas noções gerais previstas em seu art. $7^{\circ}$ possuem particular relevância na interpretação da convenção e são refletidas em seus demais dispositivos: a atenção ao caráter internacional da convenção e a boa-fé.

Muito embora o item "2" do mesmo artigo reserve o recurso à aplicação imediata desses princípios a questões "governadas, mas não reguladas" pela convenção, não seria correto se afirmar, por exemplo, que a boa-fé é aplicada apenas em caráter integrativo, suprindo as lacunas da convenção. Isto porque existem diversos dispositivos específicos no texto da convenção que são claramente informados por uma concepção de boa-fé bastante próxima àquela tratada nos capítulos precedentes deste presente trabalho, em que se falou da boa-fé no direito brasileiro, confirmando que a boa-fé (tanto objetiva como subjetiva) na CISG é antes regra do que exceção. Além do dever da mitigação de danos, objeto central deste estudo,

\footnotetext{
${ }^{76}$ AKADDAF, Fatima. Application of the United Nations Convention on Contracts for the International Sale of Goods (CISG) to Arab Islamic Countries: Is the CISG Compatible with Islamic Law Principles? Disponível em < http://www.cisg.law.pace.edu/cisg/biblio/akaddaf.html $>$ Acesso em 03/07/13.
} 
podemos citar os seguintes exemplos (a) irrevogabilidade da oferta se for razoável que o destinatário a considerasse irrevogável e tiver ele agido confiando na proposta recebida (art. 16, 2, b); (b) a aceitação tardia será considerada válida se possível a prova de que, em condições normais, teria alcançado o proponente a tempo (art. 21, 2); (c) a preclusão da invocação de uma cláusula quando o comportamento das partes assim indicar, ainda que exista disposição de que qualquer modificação no contrato tem que ocorrer por escrito (art. 29, 2); e (d) todos os amplos direitos conferidos à parte inadimplente para curar sua não performance contratual ${ }^{77}$.

Houve grande debate sobre como se daria a inclusão do termo "boafé" previsto no art. $7^{\circ}$ no texto da convenção. Como se vê, ao menos em uma interpretação meramente literal, o conceito será aplicado para suprir lacunas no texto da convenção, e não necessariamente no contrato entre as partes. Antes da entrada em vigor da convenção, que só ocorreu em janeiro de 1988, a delegação da Noruega sugeriu que o termo fosse incluído ao final do atual item 3 do art. $8^{\circ}$, que prevê disposição que em muito se assemelha à noção de boa-fé prevalecente no $\mathrm{Brasil}^{78}$ :

"(3) Para determinar a intenção de uma parte, ou o sentido que teria dado uma pessoa razoável, devem ser consideradas todas as circunstâncias pertinentes ao caso, especialmente negociações, práticas adotadas pelas partes entre si, usos e costumes e qualquer conduta subsequente das partes."

A delegação italiana foi ainda mais adiante, e sugeriu a inclusão de um artigo separado, tratando da necessidade de observância, pelas partes, da boa-fé e do princípio de cooperação internacional, dando prevalência à conduta das partes, não apenas na celebração do contrato, como em sua execução, sobre o texto da convenção e do próprio contrato ${ }^{79}$.

Para evitar a dificuldade de conceituar o termo boa-fé, as sugestões acabaram sendo rejeitadas, mantendo-se o texto original. A rejeição não significou, no entanto, que a boa-fé aplicada por força da CISG estaria

\footnotetext{
${ }^{77}$ SHEEHY, Benedict, op.cit.

${ }^{78}$ MASKOW, Dietrich; ENDERLEIN, Fritz. INTERNATIONAL SALES LAW. Op.cit.

${ }^{79}$ Idem.
} 
restrita à interpretação do texto da convenção, não havendo dúvidas entre os representantes de que se trata de um princípio que deve ser levado em conta na interpretação do contrato e da conduta das partes ${ }^{80}$. O que se quis com a rejeição das propostas sugeridas foi justamente evitar que todos os esforços para criar um ambiente seguro nas relações comerciais - o que, obviamente, depende da existência prévia de regras claras - fossem ameaçados pela valorização de um princípio irremediavelmente vago, em detrimento das normas da convenção, as quais, como se viu, já são amplamente informadas pelo princípio da boa-fé ${ }^{81}$. Ou seja, privilegia-se a boa-fé, evitando, contudo, a necessidade de se recorrer a uma cláusula geral, como ocorre no direito brasileiro.

Ainda assim, é inegável que o conceito de boa-fé é um dos pilares da convenção, e, em conjunto com a necessidade de se observar o caráter internacional da CISG, é fundamental para eliminar as incertezas do comércio internacional.

\subsection{O dever da parte lesada de mitigar seus danos na CISG}

A noção de que a parte lesada deve mitigar os danos decorrentes do inadimplemento da outra parte não é uma exclusividade da CISG no que se refere a outros textos sobre o comércio internacional. A Lei Uniforme sobre o Comércio Internacional (ULIS) já a previa em seu art. $88^{82}$ e os atuais princípios do UNIDROIT também contêm semelhante exigência ${ }^{83}$.

Em relação à redação da Lei Uniforme, é possível encontrar duas diferenças importantes introduzidas na convenção. A primeira é que foi expressamente previsto na CISG que os danos a serem mitigados incluem

\footnotetext{
${ }^{80}$ Ibid.

${ }^{81}$ Ibid.

82 "Article 88 The party who relies on a breach of a contract shall adopt all reasonable measures to mitigate the loss resulting from the breach. If he fails to adopt such measures, the party in breach may claim a reduction in the damages".

${ }^{83}$ Article 7.4.8 (Mitigation of harm) (1) The non-performing party is not liable for harm suffered by the aggrieved party to the extent that the harm could have been reduced by the later party's taking reasonabl steps. (2) The aggrieved party is entitled to recover any expenses reasonably incurred in attempting to reduce the harm.
} 
os lucros cessantes, o que não era claro na redação da Lei Uniforme ${ }^{84}$. Além disso, também foi definido que a redução no valor da indenização corresponderia ao montante que deveria ter sido mitigado pelo credor ${ }^{85}$ :

\section{“Article 77}

A party who relies on a breach of contract must take such measures as are reasonable in the circumstances to mitigate the loss, including loss of profit, resulting from the breach. If he fails to take such measures, the party in breach may claim a reduction in the damages in the amount by which the loss should have been mitigated."

Alguns pontos do dispositivo merecem particular destaque. $\mathrm{O}$ primeiro é sua inserção no capítulo que trata da indenização ("Damages"), o que impede sua aplicação, por exemplo, quando o credor exige a execução específica do contrato $^{86}$. A delegação do Estados Unidos chegou a sugerir que o mesmo princípio se aplicasse aos casos em que o credor requer a execução específica, mas esta proposta foi rejeitada ${ }^{87}$.

Como adiantado no primeiro capítulo deste trabalho, o principal ponto a ser observado no caso concreto em que se aplicará o art. 77 da CISG é a razoabilidade das medidas a serem tomadas pelo credor. Entretanto, além de todas as noções já adiantadas no primeiro capítulo deste trabalho quanto à razoabilidade das medidas a serem tomadas pelo credor e de tudo quanto se disse sobre a natureza jurídica de tal dever, devem ser destacadas algumas particularidades da CISG em relação ao dever de mitigar os próprios danos. Uma importante diferença em relação ao direito brasileiro é que o devedor só é obrigado a indenizar os danos que poderia ter previsto quando da celebração do contrato. Esta regra esta presente tanto no art. 25 quanto no art. 74 da CISG:

\footnotetext{
${ }^{84}$ KNAPP, Victor. Article 77. Disponível em <http://www.cisg.law.pace.edu/cisg/biblio/knappbb77.html > Acesso em 07/08/13.

${ }^{85}$ Idem.

${ }^{86}$ OPIE, Elisabeth. Commentary on the manner in which the UNIDROIT Principles may be used to interpret or supplement Article 77 of the CISG. Disponível em http://www.cisg.law.pace.edu/cisg/principles/uni77.html\#eo28. Acesso em 29/10/13.

${ }^{87}$ Idem.
} 
“Article 25

A breach of contract committed by one of the parties is fundamental if it results in such detriment to the other party as substantially to deprive him of what he is entitled to expect under the contract, unless the party in breach did not foresee and a reasonable person of the same kind in the same circumstances would not have foreseen such a result."

\section{“Article 74}

Damages for breach of contract by one party consist of a sum equal to the loss, including loss of profit, suffered by the other party as a consequence of the breach. Such damages may not exceed the loss which the party in breach foresaw or ought to have foreseen at the time of the conclusion of the contract, in the light of the facts and matters of which he then knew or ought to have known, as a possible consequence of the breach of contract."

Como se está lidando com comércio internacional, em que todos os esforços são voltados para a eliminação do principal custo de transação deste tipo de atividade, o risco decorrente da incerteza, a CISG limita a exposição do devedor aos riscos de que tinha (ou deveria ter) conhecimento no momento de celebração do contrato. Assim, se uma parte contrata a entrega de um determinado material para o dia $\mathrm{X}$ e, no dia seguinte, pretende dar a ele uma destinação incomum em relação aos padrões do mercado, não poderá, em princípio, responsabilizar o devedor que atrasa a entrega em dois dias pela perda daquele negócio, salvo se o informar quanto a tal fato de forma prévia à celebração do contrato. Não significa, entretanto, que o devedor não responderá por seu atraso, mas apenas que ele não poderá ser responsabilizado por um risco que desconhecia, salvo se era razoável presumi-lo diante das circunstâncias.

Sobre o tema, confira-se a lição de Joseph Lookofsky:

“290. A major component of Article 74 is the 'foreseeability' limitation familiar to many students of domestic law: damages may not exceed the loss which the breaching party foresaw or ought to have foreseen as a consequence of the breach of contract. Foreseeability under the Convention is measured at the time of the conclusion of the contract in the light of the facts and matters of which the breaching party then knew or ought to have known, the underlying idea being that the 'parties, at that point in time, should be able to calculate the risks and potential liability they assume by agreement." 88

\footnotetext{
${ }^{88}$ LOOKOFSKY, Joseph. The 1980 United Nations Convention on Contracts for the International Sale of Goods: Article 74 Damages for Breach. Disponível em < http://cisgw3.law.pace.edu/cisg/biblio/loo74.html> Acesso em 03/09/13.
} 
Trata-se de mais um importante elemento limitador das perdas e danos na CISG e que não pode ser ignorado quando se analisa o dever do credor de mitigar seus danos. Isso porque, na maior parte das vezes, a mitigação ocorre por meio de uma transação substituta feita justamente para impedir que um negócio subsequente de que tomaria parte o credor da obrigação inadimplida seja prejudicado pela falta do devedor. Analisandose, em conjunto, ambas as disposições da CISG, deve se concluir que uma transação substituta realizada pelo credor para impedir um dano que não seria atribuível ao devedor - por não ser previsível no momento da celebração do contrato - tal conduta será irrelevante para a resolução do caso concreto, uma vez que o risco já seria do próprio credor. Sequer precisará, portanto, o devedor alegar o descumprimento do dever de mitigação, bastando que prove a ausência de foresseability do prejuízo.

Já analisados os princípios que norteiam a CISG, bem como os contornos do dever de mitigar os danos, passa-se, agora, à análise de precedentes internacionais aplicando a CISG, para amplificar as constatações feitas. Os julgados a seguir tratados retraram algumas das situações tipicamente tratadas no contexto do dever de mitigação previsto na CISG: a transação substituta como forma de mitigar os danos, seja ela (a) uma revenda de bens recebidos fora de suas especificações, (b) uma nova compra junto a outro vendedor em caso dos bens não serem entregues ou (c) a venda para outro comprador em caso de recusa injustificada no recebimento; (d) a falha no dever de mitigar associada a uma tardança na inspeção de bens, que naturalmente deve ser feita quando se recebe uma mercadoria proveniente de outro país .

Tratando da situação retratada na hipótese (a) acima mencionada, confira-se o polêmico julgado conhecido como Cobalt Sulphates Case ${ }^{89}$. Um comprador alemão adquiriu de um vendedor holandês determinada quantidade de sulfato de cobalto. Apesar de não ter especificado tal circunstância expressamente no contrato, nem ter, de algum modo passível

\footnotetext{
${ }^{89}$ Bundesgerichtshof, VIII ZR 51/95, julgado em 3 de abril de 1996.
} 
de prova, informado ao vendedor de tal intenção, o comprador adquiriu os bens com o objetivo de posterior revenda para o mercado indiano. $\mathrm{O}$ vendedor, por sua vez, informou no contrato que os bens foram produzidos na Inglaterra, o que se revelou falso, pois, como se descobriu posteriormente, eles eram originários da África do Sul. Na época do apartheid vigoravam embargos a produtos sul-africanos na Índia, o que tornava os bens impróprios para o fim que o comprador os destinaria. Por isso, ele rescindiu o contrato.

Ajuizada a ação pelo vendedor, insurgindo-se contra a rescisão da avença e após interpostos recursos, o caso finalmente chegou à Corte Federal Alemã. Ao decidir a questão, equiparando os conceitos de peius entrega de bens defeituosos - e aliud - entrega de bens diversos do contratado - , ambos reunidos sob o conceito de non-conformity (CISG, art. 35) a corte entendeu que houve um inadimplemento por parte do devedor, mas que o comprador deveria ter mitigado seu dano por meio de uma revenda na própria Alemanha ou em qualquer outro local do mundo que não proibisse o comércio de bens sul-africanos. $\mathrm{O}$ rigor da decisão, típico na aplicação da CISG pelos tribunais germânicos, mostra a importância do conceito no comércio internacional, exigindo do comprador uma postura verdadeiramente proativa em relação à mitigação de seus danos.

Exemplificando a situação narrada no item (b), pode ser citado o Watches Case $^{90}$. Um comprador suíço que revendia relógios adquiriu seus produtos de um vendedor ucraniano, que, após assinar o contrato, firmou um contrato de exclusividade com outro revendedor também sediado em Kiev, e, por esse motivo, avisou que não seria capaz de entregar os bens. $\mathrm{Na}$ mesma oportunidade, o vendedor informou ao comprador o preço pelo qual poderia adquirir relógios dessa segunda revendedora ucraniana, o qual se afigurava razoável para os padrões do mercado.

Inconformado, o comprador suíço ajuizou uma demanda exigindo o pagamento da diferença do preço pelo qual ele havia acordado a futura

\footnotetext{
${ }^{90}$ Schweizerisches Bundesgericht, $\mathrm{n}^{\circ}$ 4A_440/2009 julgado em 17 de novembro de 2009.
} 
venda de relógios para seus compradores e o valor que havia sido estipulado na compra e venda celebrada com o réu. A Corte suíça, no entanto, considerou que houve descumprimento do dever de mitigar os danos por parte do comprador, já que, conforme demonstrado pelo réu, ele poderia comprar os bens da outra revendedora ucraniana e, assim, mitigar seu próprio dano.

Para ilustrar a situação tratada no item (c) acima, recorre-se ao Industrial Product Case ${ }^{91}$, envolvendo um comprador suíço e um vendedor italiano. A controvérsia se iniciou com um fax enviado pelo vendedor confirmando a venda do produto e prevendo o pagamento por letra de crédito irrevogável com vencimento para 90 dias após o conhecimento de embarque (Bill of loading - um recibo do embarque das mercadorias). Ao receber o fax, o comprador anotou, de próprio punho, a expressão "E.O. remissa Diretta" ("e/ou pagamento direto") antes de onde constava o prazo de 90 dias e reenviou a mensagem ao vendedor. Três dias depois, o vendedor enviou uma Confirmação de Encomenda (Order Confirmation), requerendo do comprador sua devolução devidamente assinada para que a venda fosse finalizada. Esta confirmação, entretanto, mantinha as condições de pagamento anteriormente estipuladas pelo devedor, ignorando a inserção feita pelo comprador. $\mathrm{O}$ documento foi assinado pelo comprador, tendo o presidente da empresa rubricado todas as suas folhas. Como se poderia presumir, instaurou-se uma controvérsia, com o comprador negando a existência de um contrato válido e questionando as condições de pagamento, porém sua insatisfação só chegou ao conhecimento do comprador quando este já havia levado a mercadoria ao porto de embarque. Premido pela necessidade de dar algum destino aos bens, o vendedor informou ao comprador que venderia os bens a um comprador das Filipinas a um preço reduzido, o que de fato se concretizou.

Passando ao largo da interessantíssima discussão a respeito da formação de contratos na CISG, a qual, por ser tão cara ao comércio

\footnotetext{
${ }^{91}$ ICC. Procedimento n ${ }^{\circ} 10329$ de 2000.
} 
internacional, seria objeto de uma convenção a parte nos projeto iniciais da UNCITRAL, é suficiente para o objeto deste estudo dizer que o tribunal arbitral decidiu esta questão em favor do vendedor, reconhecendo a existência de um contrato devidamente formado.

A venda feita ao comprador filipino a um preço reduzido foi considerada uma forma razoável de mitigar os danos, pois, o devedor não poderia pleitear o pagamento da integralidade do preço acordado se enviasse a mercadoria sabendo que o comprador não a receberia, uma vez que poderia ter evitado o dano. No entanto, o prejuízo teria sido maior se ele desistisse totalmente de vender os bens. Com a venda ao devedor Filipino, o Tribunal entendeu que o vendedor tinha direito a uma indenização correspondente à diferença entre o contrato original e o valor da revenda.

A mesma conclusão foi obtida no Mung Beans Case $^{92}$ (feijão chinês), envolvendo um comprador suíço e um vendedor chinês. Neste caso, ao contrário do que ocorreu no Industrial Products Case, as partes concordaram integralmente quanto às especificações de pagamento, que se daria por meio de letra de crédito. No entanto, até a data de embarque o comprador não havia especificado o navio no qual os bens deveriam embarcar ou respondido às cartas do vendedor sobre o embarque da mercadoria.

O comprador, então, enviou uma carta exigindo uma nova inspeção dos bens (já havia sido realizada uma no porto), antes que enviasse um navio para buscá-los no porto em que se encontravam. O vendedor redarguiu, afirmando que tal inspeção não possuía base contratual. Diante da demora do comprador em buscar os bens, e considerando o alto custo de mantê-los armazenados no porto, o vendedor realizou uma venda substituta a um comprador singapurense. Em sua decisão, o tribunal arbitral deu razão ao vendedor e entendeu que a venda substituta, feita a um valor menor do que o contrato original, seria razoável como medida de mitigação de danos.

${ }^{92}$ CIETAC. Procedimento n ${ }^{\circ}$ CISG/2001/02 julgado em 22 de março de 2001. 
Um dos mais importantes casos de aplicação do dever de mitigação dos danos é o julgado pela Corte Federal da Alemanha (Bundesgerichtshof), conhecido como o "Vine Wax Case",93, já brevemente mencionado acima quando se cuidou do ônus da prova. Neste caso, um comprador alemão, produtor de sementes de uva, adquiriu de um vendedor austríaco uma cera para ser usada em vinhas, não apenas dele, como de outras partes para as quais as revenderia.

Muito embora o comprador não tenha realizado qualquer teste para aferir sua qualidade, descobriu-se, posteriormente, que a cera vinha prejudicando a plantação. No entanto, o comprador tardou em deixar de utilizar o produto após constatar tal fato. Muito embora tenha reconhecido a não conformidade do bem objeto da compra e venda (CISG, art. 35), a Corte Federal Alemã entendeu que o credor deveria ter cessado imediatamente a utilização do produto, em atenção ao art. 77 , para que pudesse cobrar os danos de forma integral. Assim, seu direito de indenização foi reduzido em todo o valor que poderia ter sido evitado caso ele cessasse imediatamente a utilização do produto.

Neste tradicional exemplo, observa-se a situação que foi mencionada no item (d) acima, pois o credor deixou de inspecionar os bens quando chegaram e, mesmo depois de perceber os danos, continuou utilizando o produto. Seguramente, tivesse ele procedido à devida inspeção do produto, teria constatado que era ele a causa da doença que acometeu sua plantação e, com isso, evitado o prejuízo.

\footnotetext{
${ }^{93}$ Bundesgerichtshof (Corte Federal da Alemanha), VIII ZR 121/98, julgado em 24 de março de 1999.
} 
Esta monografia analisou as características gerais do dever de mitigar os danos que é imposto aos credores de responsabilidade civil, traçando os principais contornos de sua aplicação. Entre tais contornos, destacou-se que se trata de um dever que será sempre ser imposto exclusivamente ao credor, sem que a ele corresponda qualquer direito subjetivo do devedor. Além disso, foi enfatizado que o principal componente do dever de mitigação é a razoabilidade, ou seja, não se pode exigir do credor que saia do curso razoável de seus negócios para mitigar o dano. Muito embora a obrigação seja do credor, o ônus da prova deve sempre recair sobre o devedor, que deve provar a existência de medidas razoáveis a serem tomadas pelo credor para mitigar seu dano.

Em seguida, analisou-se a forma como o dever de mitigação foi importado para o direito brasileiro. Como se viu, o instituto foi imediatamente associado ao conceito de boa-fé objetiva. Sua aplicação, contudo, não tem observado - em muitos casos nem minimamente - os contornos que a doutrina e a jurisprudência internacional, que aplicam o referido instituto há pelo menos um século, consagraram. Como consequência, acabou sendo absorvido no Brasil sob a forma de uma ideia geral e vaga, sem contornos precisos, sendo aplicado até mesmo em favor do devedor, o que é absolutamente contrário à lógica do instituto.

Também foi observada a falta de maiores discussões sobre a razoabilidade na medida a ser tomada pelo credor. Este é o principal ponto que deve reger o dever de mitigação, impedindo que venha a se tornar fonte de injustiças contra as partes inocentes. De igual modo, notou-se uma ausência de julgados em relação a transações substitutas feitas com o intuito de mitigar danos, as quais são fundamentais para que o dever de mitigar cumpra seu papel de impedir que um inadimplemento seja o motivo de um abandono pelo credor da tentativa de obter o resultado prático do contrato. 
É necessária uma reflexão sobre o instituto, não apenas para aprimorar a técnica de nossas decisões judiciais, mas também para que, ao aplicar a CISG a partir de abril de 2014, os tribunais pátrios não violem seu caráter internacional e a necessidade de uniformidade na sua aplicação, expressamente previstos no art. 7(1) da convenção ${ }^{94}$.

Com a incorporação da CISG ao ordenamento jurídico brasileiro é provável que questões cada vez mais intrincadas envolvendo o dever de mitigação surjam perante nossos tribunais, e será necessário que os julgadores estejam devidamente familiarizados com o instituto. Isto porque os litígios internacionais são uma realidade no Brasil e é preciso que nossas decisões não destoem demasiado dos precedentes internacionais aplicando o mesmo corpo de normas de forma a não afetar o equilíbrio e homogeneidade que se buscou ao se formular a convenção.

\footnotetext{
${ }^{94}$ In the interpretation of this Convention, regard is to be had to its international character and to the need to promote uniformity in its application and the observance of good faith in international trade.
} 


\section{Doutrina:}

AKADDAF, Fatima. Application of the United Nations Convention on Contracts for the International Sale of Goods (CISG) to Arab Islamic Countries: Is the CISG Compatible with Islamic Law Principles? Disponível em < http://www.cisg.law.pace.edu/cisg/biblio/akaddaf.html > Acesso em 03/07/13.

CRUZ, Gisela Sampaio da Cruz. O Problema do Nexo Causal na Responsabilidade Civil. Rio de Janeiro: Editora Renovar. 2005

CORDEIRO, António Manuel da Rocha e Menezes. Tratado de direito civil português: direito das obrigações, cumprimento e não cumprimento, transmissão modificação e extinção, garantias. Coimbra: Almedina, 2010. vol. II

I.

. Da Boa Fé no Direito Civil. Coimbra: Almedina. 1984. Vol.

DIAS, Daniel Pires de Novais. O Duty to Mitigate the Loss no Direito Civil Brasileiro e o Encargo de Mitigar o Próprio Dano. In: TEPEDINO, Gustavo; FACHIN, Edson. Revista dos Tribunais. Doutrinas Essenciais: Obrigações e Contratos, vol. III. São Paulo: Editora Revista dos Tribunais. 683-738p.

DIDIER JR, Fredie., Multa Coercitiva, Boa-Fé Processual e Supressio: Aplicação do Duty To Mitigate the Loss no Processo Civil. Revista de Processo, vol. 171, ano 34, 46-47p.

DYSON, Andrew. British Westinghouse Revisited. Disponível em $<$ http://www.academia.edu/1987110/British_Westinghouse_Revisited $>$.

Data de Acesso 5/10/13.

FRADERA, Vera Maria Jacob de. Pode o credor ser instado a diminuir o próprio prejuízo? Revista Trimestral de Direito Civil no 19. 109-119p.

HONNOLD, John O. Uniform Law for International Sales under the 1980 United Nations Convention. Disponível em $<$ http://www.cisg.law.pace.edu/cisg/biblio/honnold.html $>$ Acesso em 02/07/13 
KNAPP, Victor. Article $77 . \quad$ Disponível em $<$ http://www.cisg.law.pace.edu/cisg/biblio/knapp-bb77.html $>$ Acesso em $07 / 08 / 13$

KOMAROV, Alexander. Mitigation of Damages. In DERRAINS, Yves e KREINDLER, Richard (coord.), Evaluation of Damages in International Arbitration. Paris: International Chamber of Commerce. 2006, 37p.

KRÖLL, Stefan. Selected Problems Concerning the CISG's Scope of Application. Disponível em $<$ http://www.cisg.law.pace.edu/cisg/biblio/kroll.html > Acesso em 04/07/13.

LEITE, Gisele. Roteiro sobre o princípio da boa fé objetiva. Disponível em http://www.egov.ufsc.br/portal/conteudo/leite-gisele-roteiro-sobre-oprinc\%C3\%ADpio-da-boa-f\%C3\%A9-objetiva Acesso em 1/10/13

LOOKOFSKY, Joseph. The 1980 United Nations Convention on Contracts for the International Sale of Goods: Article 74 Damages for Breach. Disponível em <http://cisgw3.law.pace.edu/cisg/biblio/loo74.html $>$ Acesso em $03 / 09 / 13$

MIRANDA, Pontes de. Tratado de Direito Privado: Parte Especial. Tomo XLVI, Direito das Obrigações; Seguros. Atualizado por MIRAGEM, Bruno. São Paulo: Editora Revista dos Tribunais. 2012.

MASKOW, Dietrich; ENDERLEIN, Fritz. INTERNATIONAL SALES LAW. Disponível em <http://cisgw3.law.pace.edu/cisg/biblio/enderleinart77.html.> Acesso em 02/04/13

MCMAHON, John. Drafting CISG Contracts and Documents and Compliance Tips for Traders. Disponível em http://cisgw3.law.pace.edu/cisg/contracts.html\#a77. Acesso em 19/10/13.

MUÑOZ, Edgard; MOZER, Luiz Gustavo Meira, A Adesão do Brasil à CISG: Consequências para o Comércio na China e América Latina. Revista Brasileira de Arbitragem no 34, 2012, 56-57p.

NALIN, Paulo e SIRENA, Hugo. A Convenção de Viena de 1980 e a Sistemática Contratual Brasileira: A Recepção Principiológica do Duty to Mitigate the Loss. Revista Jurídica, no 422, 37p.

OPIE, Elisabeth. Commentary on the manner in which the UNIDROIT Principles may be used to interpret or supplement Article 77 of the CISG. Disponível em http://www.cisg.law.pace.edu/cisg/principles/uni77.html\#eo28. Acesso em $29 / 10 / 13$ 
PEIXOTO, Alessandra Cristina Tufvesson. Responsabilidade extracontratual: Algumas considerações sobre a participação da vítima na quantificação da indenização. Revista da EMERJ, n.44, Rio de Janeiro, 2008, 135-136p.

PEREIRA, Cáio Mário da Silva. Instituições de Direito Civil. vol. I. 22a edição, Rio de Janeiro: Editora Forense. 2008. 580p.

- Instituições de Direito Civil. vol. II. $13^{\mathrm{a}}$ edição, Rio de Janeiro: Editora Forense. 2009. 7p.

PERLINGIERI, Pietro. Perfis do direito civil: introdução ao direito civil constitucional. Trad. Maria Cristina de Cicco. Rio de Janeiro: Renovar, 1997.

PRAGER, Dietmar; FRISCHTAK, Ana. Duke Energy International Peru Investments No. 1, Ltd. v. Republic of Peru, Award, ICSID Case No. ARB/03/28, 18 August 2008: a contribution by the ITA Board of Reporters. Disponível em $<$ http://www.kluwerarbitration.com/CommonUI/document.aspx?id=ipn912 04\&query $=\mathrm{AND}(\mathrm{ONEAR} / 0$ (content $\% 3 \mathrm{~A} \% 22$ mitigation $\% 22$, content $\% 3 \mathrm{~A} \%$ 22of $\% 22$, content $\% 3 \mathrm{~A} \% 22$ damages $\% 22$ ), content $\% 3 \mathrm{~A} \% 22$ reasonability $\% 22$ $>$. Acesso em 26/9/13.

RODRIGUES NETO, Nelson in Alvim, Arruda e Alvim, Thereza (coord.) Comentários ao Código Civil Brasileiro. São Paulo: Editora Forense. 2004, $283 p$.

SAIDOV, Djakhongir. Methods of Limiting Damages under the Vienna Convention on Contracts for the International Sale of Goods. Disponível em http://cisgw3.law.pace.edu/cisg/biblio/saidov.html\#iv. Acesso em $10 / 10 / 13$

SHEEHY, Benedict. Good Faith in the CISG: Interpretation Problems in Article $7 . \quad$ Disponível em < http://law.bepress.com/cgi/viewcontent.cgi?article $=1815 \&$ context=expresso $>$ Acesso em 03/07/13

TARTUCE, Flávio. Função Social dos Contratos - do Código de Defesa do Consumidor ao Código Civil de 2002, $2^{a}$ ed., Método, São Paulo, 2007, pp. 209 e 211

TEIXEIRA, Sálvio de Figueiredo (Org.). Comentários ao Novo Código Civil. Rio de Janeiro: Forense. 2003. 1-43p. 
TRABUCCHI, Alberto. Instituzioni di Diritto Civile. Padova: CEDAM. 1990.

\section{Jurisprudência:}

Bundesgerichtshof, VIII ZR 51/95, julgado em 3/4/96

Bundesgerichtshof. VIII ZR 121/98. Julgado em 24/3/99

CIETAC. Procedimento $\mathrm{n}^{\circ}$ CISG/2000/06, julgado em 7 de janeiro de 2000.

CIETAC. Procedimento $n^{\circ}$ CISG/2001/02 julgado em 22 de março de 2001.

ICC. Procedimento no 8574 julgado em Setembro de 1996

ICC. Procedimento nº 10329 de 2000.

IUSCT. Procedimento $\mathrm{n}^{\mathrm{o}} 430$ (438-430-1), julgado em 5 set. 1989. Publicado em BERG, Albert Jan van den (ed), Yearbook Commercial Arbitration 1990 - Volume XV, Kluwer Law International: 1990239 $255 \mathrm{p}$.

Oberlandesgericht Köln. 18 U 121/97. Julgado em 21/8/97

Oberster Gerichtshof (Austria), Caso n 7 Ob 301/01t, Viena. Julgado em $14 / 1 / 12$

Schweizerisches Bundesgericht, no 4A_440/2009 julgado em 17 de novembro de 2009

STJ. HC 266.426/SC, Relatora Ministra Maria Thereza de Assis Moura, Sexta Turma, julgado em 07/05/2013, DJe 14/05/2013

STJ. HC 171.753/GO, Relatora Ministra Maria Thereza de Assis Moura, Sexta Turma, julgado em 04/04/2013, DJe 16/04/2013

STJ. HC 137.549/RJ, Relatora Ministra Maria Thereza de Assis Moura, Sexta Turma, julgado em 07/02/2013, DJe 20/02/2013

STJ. HC 131.830/SP, Rel. Ministra Maria Thereza de Assis Moura, Sexta Turma, julgado em 18/12/2012, DJe 01/02/2013.

STJ. HC 266.426/SC, Rel. Ministra Maria Thereza de Assis Moura, Sexta Turma, julgado em 07/05/2013, DJe 14/05/2013 
STJ. REsp $n^{\circ}$ 1274629/AP, Relatora Ministra Nancy Andrighi, Terceira Turma, julgado em 16/05/2013, DJe 20/06/2013

STJ. REsp n ${ }^{\circ}$ 256.274/SP. Rel. Ministro Ruy Rosado de Aguiar, Quarta Turma, julgado em 26/09/2000, DJ 18/12/2000

STJ. REsp $n^{\text {o } 32890 / S P . ~ R e l . ~ M i n i s t r o ~ R u y ~ R o s a d o ~ d e ~ A g u i a r, ~ Q u a r t a ~}$ Turma, julgado em 14/11/1994, DJ 12/12/1994

STJ. REsp $\mathrm{n}^{\mathrm{o}}$ 758518/PR, Relator Ministro Vasco Della Giustina (desembargador convocado do TJ/RS), Terceira Turma, julgado em 17/06/2010, DJe 28/06/2010

TJRS. Apelação Cível no 70028138113, Décima Segunda Câmara Cível, Relator Des. Umberto Guaspari Sudbrack, Julgado em 29/01/2009

\section{Outros:}

Nota explicativa da Secretaria da Comissão das Nações Unidas sobre o Direito do Comércio Internacional. Disponível em $<$ http://cisgw3.law.pace.edu/cisg/text/secomm/secomm-77.html. $>$ Acesso em $02 / 04 / 13$

Lista de países signatários. Disponível em $<$ http://treaties.un.org/> Acesso em 25/06/2013.

Notícia publicada no site da Organização das Nações Unidas. Disponível em <http://www.onu.org.br/brasil-adere-a-convencao-da-onu-sobrecontratos-internacionais-de-compra-e-venda-de-mercadorias/ acessado em 25/06/2013 às 11:21> Acesso em 02/06/13 